\title{
Strain-Specific Hypersensitive and Extreme Resistance Phenotypes Elicited by Potato virus Y Among 39 Potato Cultivars Released in Three World Regions Over a 117-Year Period
}

Roger A. C. Jones, ${ }^{\dagger}$ Department of Agriculture and Food, Bentley Delivery Centre, WA 6983, Australia; and Institute of Agriculture, University of Western Australia, Crawley, Perth, WA 6009, Australia; and Stuart J. Vincent, Department of Agriculture and Food, Bentley Delivery Centre, WA 6983, Australia

\begin{abstract}
Strain-specific hypersensitive (HR) and extreme resistance (ER) phenotypes elicited in potato plants by three Potato virus $Y(\mathrm{PVY})$ isolates in strain groups $P V Y^{\mathrm{O}}$ (BL and DEL3) and $\mathrm{PVY}^{\mathrm{D}}$ (KIP1) were studied. $\mathrm{PVY}^{\mathrm{O}}$ and $\mathrm{PVY} \mathrm{P}^{\mathrm{D}}$ isolates elicit HR genes $N y$ or putative $N d$, respectively, and all three isolates elicit ER gene Ry. They were inoculated to 39 Australasian, European, or North American potato cultivars released over a 117-year period and harvested tubers were replanted. Both primary and secondary symptoms were recorded. Two European cultivars always developed ER following sap and graft inoculation and, thus, carried comprehensive PVY resistance gene Ry. One Australasian and two European cultivars always developed susceptible phenotypes and, thus, lacked genes $R y, N y$, and putative $N d$. Sap inoculation with isolate KIP1 elicited localized HR (LHR) in 31 cultivars and both LHR and systemic HR (SHR) in three others; thus, all carried putative $N d$. Isolates BL and DEL3 both elicited susceptible phenotypes in 11 of these 34 cultivars but LHR alone, SHR

alone, or both LHR and SHR in the other 23 which, therefore, all carry $N y$. With these two isolates, SHR expression ranged from very severe to very weak, with the greatest numbers of isolate-cultivar combinations occurring in the severe category with $\mathrm{BL}(n=11)$ and moderate category $(n=$ 12) with DEL3. Within the same isolate-cultivar combination, overall, SHR symptom expression was weaker with secondary than primary infection. With both primary and secondary infection, SHR expression was most severe with KIP1 and weakest with DEL3. Genes $N y$ and putative $N d$ were present in cultivars released between 1939 and 2010 or 1893 and 2010, respectively, occurring in cultivars from all three world regions. These findings have important implications concerning breeding new PVY-resistant potato cultivars, especially for countries lacking healthy seed potato stocks, or where subsistence farmers cannot afford them. An alternative to including gene $R y$ is incorporating as many strain-specific PVY resistance genes as possible.
\end{abstract}

Potato (Solanum tuberosum) is one of the most important food crop globally (FAOSTAT 2017). It suffers greatly from debilitating virus diseases (De Bokx and van der Want 1987; Jones 1981, 2014; Loebenstein et al. 2001; Stevenson et al. 2001). Potato virus Y (PVY; family Potyviridae, genus Potyvirus) recently overtook Potato leaf roll virus (PLRV; family Luteoviridae, genus Polerovirus) to become the most important virus disease of potato worldwide (Jones 2014; Karasev and Gray 2013a; Singh et al. 2008). Moreover, PVY was recently ranked as the fifth most important plant virus (Scholthof et al. 2011). PVY causes substantial losses in potato tuber yield, diminishes tuber quality by causing potato tuber necrotic ringspot disease (PTNRD) in sensitive cultivars, and disrupts healthy seed potato production (Gray et al. 2010; Jones 2014; Karasev and Gray 2013a; Valkonen 2007). The virus has a single-stranded, positive-sense RNA genome of approximately $9.7 \mathrm{~kb}$. It is nonpersistently aphidborne (Karasev and Gray 2013a; Kerlan 2006) and is also contact transmissible (Coutts and Jones 2015). It also causes important diseases in other solanaceous crops, including tobacco (Nicotiana tabacum), tomato (S. esculentum), and pepper (Capsicum annum) (Blanchard et al. 2008; Kerlan 2006; Kerlan and Moury 2008).

In potato or other crop plants infected with viruses, hypersensitive resistance (HR) phenotypes result when gene-for-gene interactions occur between a virus hypersensitivity gene and a virus gene. Depending on whether the virus spreads out of sap-inoculated leaves, HR phenotypes can be localized (LHR) or systemic (SHR) (Jones 1981, 1990, 2014; Kehoe and Jones 2016; Kim et al. 2008; Nyalugwe et al. 2016; Ravelo et al. 2007). Both LHR and SHR involve development of necrotic local lesions in inoculated leaves but, when

${ }^{\dagger}$ Corresponding author: R. A. C. Jones; E-mail: roger.jones@agric.wa.gov.au Accepted for publication 6 August 2017.

@ 2018 The American Phytopathological Society systemic necrosis develops, it frequently leads to individual shoot or entire plant death (del Pozo and Lam 2003; Hajimorad et al. 2005; Jones 1990; Jones and Smith 2005; Kehoe and Jones 2016; Nyalugwe et al. 2016). Moreover, viruses causing LHR after sap inoculation induce SHR after graft inoculation (Jones 1990) and can be controlled by the same hypersensitivity inducing resistance gene (Kehoe and Jones 2016; Kim et al. 2008; Ravelo et al. 2007). In the field, SHR works at the plant population level by diminishing virus spread from plant to plant, whereas LHR limits virus spread within individual plants. SHR is most effective when infected plants die rapidly because this removes them as internal crop infection foci, thus preventing secondary virus spread (Cheng et al. 2002; Jones 2005; Jones and Smith 2005; Jones et al. 2003; Kim et al. 2008; Thackray et al. 2002).

Biological strain groups (i.e., pathotypes) consisting of PVY isolates from potato are distinguished from each other by whether they elicit HR in potato cultivar differentials carrying hypersensitivity genes or systemic veinal necrosis symptoms in tobacco. Strain groups $\mathrm{PVY}^{\mathrm{C}}, \mathrm{PVY}^{\mathrm{O}}$, and $\mathrm{PVY}^{\mathrm{Z}}$ elicit $\mathrm{HR}$ phenotypes with hypersensitivity genes $N c, N y$, or $N z$, respectively. Strain groups $\mathrm{PVY}^{\mathrm{N}}$ and $\mathrm{PVY}^{\mathrm{E}}$ overcome all three hypersensitivity genes but differ in the phenotypes they induce in tobacco, with only $\mathrm{PVY}^{\mathrm{N}}$ eliciting veinal necrosis (Chikh-Ali et al. 2014; Cockerham 1970; Davidson 1980; Jones 1990; Karasev and Gray 2013a,b; Kehoe and Jones 2016; Rowley et al. 2015; Singh et al. 2008). However, lack of inoculation to potato differentials with $N c, N y$, or $N z$ means that many biologically defined, so-called "PVY" isolates are merely ones that fail to cause veinal necrosis phenotypes in tobacco. Therefore, they could belong to PVYC ${ }^{\mathrm{C}}$ PVY ${ }^{\mathrm{E}}$, or PVY ${ }^{\mathrm{Z}}$ instead (Jones 2014; Kehoe and Jones 2011, 2016). Cockerham (1939) confirmed the effectiveness of $N c$ at decreasing $\mathrm{PVY}^{\mathrm{C}}$ spread in the field. The degree of resistance offered by gene $N y$ varies from cultivar to cultivar but is more effective in the field than in inoculation studies (Davidson 1980).

Early studies suggested the existence of an additional PVY strain group that caused HR in the absence of genes $N c$ and $N y$ (Davidson 1980; Davidson and Butzonitch 1978a,b). PVY isolate Rs118 from 
S. tuberosum subsp. andigena clone CPC188 (Hovarth 1967) induced HR in all of the 17 British potato cultivars or breeding lines inoculated with it. Moreover, these not only included cultivars that carried genes $N c$ or $N y$ but also some that did not (Davidson 1980; Davidson and Butzonitch 1978a,b). They also included cultivars that lacked gene $N z$ (Chikh Ali et al. 2014; Jones 1990); thus, this strain group could not have been the later-recognized PVYZ. There were no further reports of PVY isolates behaving like this until recent studies with PVY isolates from Australia, where Kehoe and Jones (2016) found an additional strain group that elicited HR phenotypes not only in the absence of genes $N c$ and $N y$ but also in the absence of gene $N z$. They named this strain group $\mathrm{PVY}^{\mathrm{D}}$ and named the putative hypersensitivity gene involved $N d$.

Previously, potato biological strain groups $\mathrm{PVY}^{\mathrm{C}}$ and $\mathrm{PVY}^{\mathrm{O}}$ were thought to coincide with major phylogroups $\mathrm{PVY}^{\mathrm{C}}$ and $\mathrm{PVY} \mathrm{Y}^{\mathrm{O}}$, respectively (Barker et al. 2009; Blanco-Orgoiti et al. 1998; Boonham et al. 2002). However, this proved incorrect because isolates within biological strain groups $\mathrm{PVY}^{\mathrm{D}}$ and $\mathrm{PVY}^{\mathrm{Z}}$ fitted within phylogroups $\mathrm{PVY}^{\mathrm{C}}$ and PVY ${ }^{\mathrm{O}}$, respectively (Kehoe and Jones 2016). As the number of complete PVY genome sequences from different world regions grows, phylogenetic nomenclature based on biological, geographical, and sequence names is becoming increasingly unsustainable; therefore substituting Latinized numerals for current phylogroup names was suggested (Jones 2014; Jones and Kehoe 2016; Kehoe and Jones 2016). When Gibbs et al. (2017) examined the phylogenetics of the global population of PVY isolates with complete genomes, $42 \%$ were nonrecombinants and $58 \%$ were recombinants. The nonrecombinants were all within major phylogroups $\mathrm{PVY}^{\mathrm{C}}, \mathrm{PVY}^{\mathrm{N}}$, or $\mathrm{PVY}^{\mathrm{O}}$, whereas recombinants between $\mathrm{PVY}^{\mathrm{N}}$ and $\mathrm{PVY} \mathrm{O}^{\mathrm{O}}$ were in major phylogroups R-1 or R-2. The principal parents of R-1 and R-2 were $\mathrm{PVY}^{\mathrm{N}}$ and $\mathrm{PVY} \mathrm{Y}^{\mathrm{O}}$, respectively, and vice versa for their secondary parents. The minor phylogroups within these major phylogroups, with roman numerals from the PVY classification system of Kehoe and Jones (2016) in parentheses, were $\mathrm{C}$ with $\mathrm{C} 1$ (II) and C2 (III); O with $\mathrm{O}$ (= I) and O5 (= X); N with Eu-N (= IV), XIII, and NA-N (= IX); R-1 with SYR-I (XII), NTN-B (VI), SYR-II (XI), N-Wi (VII), and N:O (VIII); and R-2 with NTN-A (V) (Gibbs et al. 2017). Recent investigations with North American potato cultivars identified five additional putative hypersensitivity genes called $\mathrm{Nw}, \mathrm{Nna}, \mathrm{Nne}, \mathrm{Ne}$, and $\mathrm{Nn}$ (Kerlan et al. 2011; Rowley et al. 2015). These resulted in HR phenotypes following infection with biological strain groups $\mathrm{PVY}^{\mathrm{N}}(\mathrm{Nn})$ and $\mathrm{PVY} \mathrm{Y}^{\mathrm{E}}$ $(\mathrm{Ne})$, or the RNA sequence defined minor phylogroups $\mathrm{PVY}^{\mathrm{N}-\mathrm{Wi}}$ $\mathrm{PVY}^{\mathrm{N}: \mathrm{O}}(N w), \mathrm{PVY}^{\mathrm{NA}-\mathrm{N}}(N n a)$, and PVY-NE11 (Nne) (Kerlan et al. 2011; Rowley et al. 2015).

Although there have been several relevant studies (Bald and Norris 1945; Bawden and Kassanis 1946; Bawden and Sheffield 1944; Chikh-Ali et al. 2013; Cockerham 1943; Howard and Fuller 1965; Hutton 1945, 1946, 1948; Hutton and Bald 1945; Jones 1987, 1990; Kehoe and Jones 2016; Nie et al. 2012; Rowley et al. 2015; Valkonen and Makarainen 1993), comprehensive information is lacking concerning expression of LHR and SHR phenotypes arising from primary (i.e., current-season) infection with PVY in potato cultivars from different world regions. Moreover, very few studies also investigated SHR expression arising from secondary (i.e., tuberborne) infection (Jones 1990; Nie et al. 2012; Valkonen and Makarainen 1993). Similarly, no published studies provided comprehensive information over the occurrence of hypersensitivity genes $N c$ and $N y$, the more recently discovered hypersensitivity genes $N z$ or putative $N d$, or comprehensive hypersensitivity genes $N y-1$ and $N y-2$ (Szajko et al. 2008, 2014) and extreme resistance (ER) gene $R y$ (Cockerham 1970), among potato cultivars bred in different continents or released in different eras. In this study, we examined the phenotypes elicited by different PVY isolates following infection of 39 potato cultivars originally from Australasia, Europe, or North America. The cultivars included were released over a 117-year period and all are available within Australia. Although most lack such information, several are known to carry one or more of the hypersensitivity genes $N c, N y$, $N z$, or putative $N d$ (Cockerham, 1943; Jones 1990, Kehoe and Jones 2011, 2016; Kerlan et al. 2011; Nie et al. 2012; Rowley et al. 2015). The biological strain groups known to occur in Australia are PVYO,
$\mathrm{PVY}^{\mathrm{Z}}, \mathrm{PVY}^{\mathrm{C}}, \mathrm{PVY}^{\mathrm{N}}$, and PVY ${ }^{\mathrm{D}}$ (Buchen-Osmond et al. 1988; Heath et al. 1987; Kehoe and Jones 2011, 2016). The three PVY isolates used

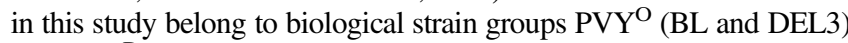
and $\mathrm{PVY}^{\mathrm{D}}$ (KIP1). None are recombinants and all three fit within two minor phylogroups, either in a new one tentatively named $\mathrm{PVY}^{\mathrm{C} 3}$ by Green et al. (in press) for KIP1, or in $\mathrm{PVY}^{\mathrm{O} 5}(=\mathrm{X})$ as reported by Kehoe and Jones (2016) for BL and DEL3. Our aims were to provide comprehensive information from potato cultivars originating in three different world regions over a $>100$-year time frame on (i) the occurrence and expression of strain-specific LHR and SHR phenotypes resulting from primary and secondary infection with $\mathrm{PVY}^{\mathrm{O}}$ and $\mathrm{PVY}^{\mathrm{D}}$; (ii) how widespread potato hypersensitivity genes $N y$ and putative $N d$ are within such cultivars; and (iii) how common comprehensive hypersensitivity and ER phenotypes, reflecting the presence of genes $N y-1$ or $N y$-2 and gene $R y$, respectively, are among them. Our intention was to use the information obtained to make recommendations to potato breeders concerning incorporation of strain group-specific virus resistance genes into future virus-resistant potato cultivars not only for developed countries but also for developing countries lacking healthy seed potato programs or where subsistence farmers are unable to purchase healthy seed tubers.

\section{Materials and Methods}

Virus isolates and plants. PVY isolates BL, DEL3, and KIP1 were obtained previously from PVY-infected potato plants growing in Western Australia (Kehoe and Jones 2011, 2016). Plants of White Burley tobacco and 39 potato cultivars (nine originally from Australasia, 19 from Europe, and 11 from North America) were grown from planting of tubers to tuber harvest in standard potting mix, within insect-proof, air-conditioned glasshouses at approximately $20^{\circ} \mathrm{C}$ under natural lighting. To ensure thorough aphid control, the insecticide imidacloprid was applied to all plants regularly. The potato cultivars used and details of their countries of origin, years of release, parentage, and available information on PVY resistance genes are listed in Table 1. These cultivars were obtained as healthy seed tubers from the Department of Agriculture and Food Western Australia, or as tissue cultured, virus-tested mini-tubers from the Victorian Department of Primary Industries, Toolangi Elite Ltd. or the University of Tasmania.

Inoculations, symptom recording, and sample testing. Infective sap was inoculated to White Burley tobacco plants in which cultures of each isolate were maintained by serial subculture. Manual inoculations were done by grinding PVY-infected leaves diluted in extraction buffer containing disodium hydrogen phosphate $\left(\mathrm{Na}_{2} \mathrm{HPO}_{4}\right.$ at $11.5 \mathrm{~g} /$ liter $)$ and monosodium phosphate $\left(\mathrm{NaH}_{2} \mathrm{PO}_{4}\right.$ at $3 \mathrm{~g} /$ liter) to give a threefold dilution of sap with buffer. The extracted sap was mixed with "celite" (diatomaceous earth) before being rubbed onto leaves of healthy plants when their emerging shoots had grown three to five fully expanded leaves. Mock inoculations were done similarly, except that healthy tobacco leaves were ground instead of PVY-infected ones. To observe primary foliage symptoms, for each isolate-cultivar combination, two to six (KIP1) or three to six (BL and DEL3) plants of each cultivar were inoculated with each isolate. The inoculations with BL, DEL3, and KIP1 to the key differential Desiree (nc:Ny:nz:putative $N d$ ) and King Edward (Nc:ny:nz:putative $N d$ ) tobacco were each repeated one to two times. The phenotypes resulting from inoculation to the other cultivars were always clear, except in a few instances where mild or very mild SHR phenotypes developed with isolates BL and DEL3; therefore, these inoculations were repeated to new plants. Plants of each cultivar (two to four) were also mock inoculated with healthy sap as controls. All inoculated plants were inspected weekly for symptoms for 10 weeks after inoculation, and the symptoms that developed were recorded. Samples from inoculated and noninoculated upper leaves from each isolate-cultivar combination and from the mock-inoculated plants were tested for PVY presence by enzyme-linked immunosorbent assay (ELISA) after 3 to 4 weeks and 4 to 10 weeks, respectively. No virus was ever detected in samples from mock-inoculated plants. In addition, the tubers harvested from all the inoculated potato plants belonging to each isolate-cultivar combination were washed clean, stored at $4^{\circ} \mathrm{C}$, and then examined for symptoms of PTNRD. 
To record secondary foliage symptoms, for each PVY isolatecultivar combination, five to six (BL and DEL1) or two to six (KIP1) tubers harvested from infected plants were sprouted and planted. These were observed for symptoms over a 10 -week period after plant emergence. Samples from upper leaves were tested for PVY presence by ELISA 4 to 10 weeks after emergence. As with the inoculated plants, the tubers harvested from all of the secondarily infected potato plants belonging to each isolate-cultivar combination were examined for PTNRD symptoms.

Plants of each of the two potato cultivars which sap inoculation failed to infect with PVY (Lady Crystl and Royal Blue) were trimmed down to two shoots, each of which was wedge grafted with a scion infected with isolates BL, DEL3, or KIP1 (three plants/ isolate), as described previously (Jones 1990; Noordham 1973). Plants of Innovator and MacRusset potato were graft inoculated similarly with isolate BL. The scions were from infected plants of Bliss (BL and DEL3) or White Burley tobacco (KIP1). In addition, healthy scions were graft inoculated in the same way to control plants of Lady Crystl, Royal Blue, Innovator, and MacRusset. All graft-inoculated plants were observed for symptoms for up to 10 weeks. With each isolate-cultivar and control plant combination, after 4 to 10 weeks, samples from young upper leaves were tested for PVY presence by ELISA.

ELISA. Leaf samples were tested for PVY by double-antibody sandwich ELISA (Clark and Adams 1977). They were extracted $(1 \mathrm{~g}$ per $20 \mathrm{ml})$ in phosphate-buffered saline $(10 \mathrm{mM}$ potassium phosphate and $150 \mathrm{mM}$ sodium chloride, $\mathrm{pH} 7.4$ ), Tween 20 at $5 \mathrm{ml} / \mathrm{liter}$, and polyvinyl pyrrolidone at $20 \mathrm{~g} /$ liter using a mixer mill (Retsch). All samples were tested in duplicate wells in microtiter plates, and sap from PVY-infected and healthy leaf samples were included in paired wells as controls. The substrate was p-nitrophenyl phosphate at $0.6 \mathrm{mg} / \mathrm{ml}$ in diethanolamine $(\mathrm{pH} \mathrm{9.8)} \mathrm{at} 100 \mathrm{ml} /$ liter. Absorbance values at $405 \mathrm{~nm}$ were measured in a Bio-Rad microplate reader (model 680; Bio-Sys). Positive values were always more than three

Table 1. Origins and parentage of the 39 potato cultivars studied, and published occurrence of Potato virus $Y$ resistance genes ${ }^{\mathrm{a}}$

\begin{tabular}{|c|c|c|c|c|}
\hline Cultivar & Origin & Year of release & Parents & Virus resistance gene information \\
\hline Almera & The Netherlands & 1999 & $2102 / 77 / 2698 \times$ AR $80-31-20$ & \\
\hline Atlantic & United States & 1976 & Wauseon $\times$ Lenape & $N y, n z$, putative $N d$ (Kehoe and Jones 2016) \\
\hline Banana & Russia? & Before 1925 & Unavailable & $n y, n z, n d($ Kehoe and Jones 2016) \\
\hline Bliss & Australia & 2000 & Atlantic $\times$ Lindsey & $n y, n z$, putative $N d$ (Kehoe and Jones 2016) \\
\hline Canberra & The Netherlands & 2010 & Unavailable & $\ldots$ \\
\hline Desiree & The Netherlands & 1962 & Urgenta $\times$ Depesche & $\begin{array}{l}n c, N y, n z \text {, putative } N d \text { (Jones 1990; Kehoe } \\
\text { and Jones 2016; Rowley et al. 2015) }\end{array}$ \\
\hline Dutch Cream & Australia & 1962 & 1973 selection from Nicola & $\ldots$ \\
\hline FL1867 & United States & 2004 & FL $162 \times$ Atlantic & $\ldots$ \\
\hline FL 2137 & United States & 2008 & FL $2006 \times$ FL 1291 & $\ldots$ \\
\hline FL 2195 & United States & NR & Unavailable & $\ldots$ \\
\hline FL 2204 & United States & 2009 & FL $1867 \times$ Andover & ny, putative $N d$ (Kehoe and Jones 2016) \\
\hline FL 2215 & United States & 2009 & FL $1840 \times$ FL 1867 & $\ldots$ \\
\hline Granola & Germany & 1975 & $3333-60 \times 267-04$ & $\ldots$ \\
\hline Harmony & United Kingdom & 1998 & Nadine $\times$ Stamina & $\ldots$ \\
\hline Innovator & The Netherlands & 1999 & Shepody $\times$ RZ-84-2580 & $n y, n z$, putative $N d$ (Kehoe and Jones 2016) \\
\hline Kestrel & United Kingdom & 1992 & Seedling $\times$ Cara & $\ldots$ \\
\hline King Edward & United Kingdom & 1902 & Magnum Bonham $\times$ Beauty of Hebron & $\begin{array}{l}N c, n y, n z \text {, putative } N d \text { (Cockerham 1943; } \\
\text { Jones 1990; Kehoe and Jones 2016) }\end{array}$ \\
\hline Kipfler & Austria & Before 1925 & 1956 selection from Banana & $n y, n z, n d$ (Kehoe and Jones 2016) \\
\hline Lady Crystl & The Netherlands & NR & WS 73-3-391 $\times$ Mansour & $\ldots$ \\
\hline Lustre & Australia & 1999 & Crystal $\times$ Wilwash & $\ldots$ \\
\hline MacRusset & Australia & 1996 & Lemhi Russet $\times$ Maris Piper & $n y, n z, n d($ Kehoe and Jones 2016) \\
\hline Maxine & United Kingdom & 1994 & Antar $\times 93 / 2$ & $\ldots$ \\
\hline Mondial & The Netherlands & 1987 & Spunta $\times$ VE 66-295 & $\ldots$ \\
\hline Nadine & United Kingdom & 1987 & Solanum vernei polycross & $\begin{array}{l}N y, N z \text {, putative } N d \text { (Kehoe and Jones 2011, } \\
\text { 2016) }\end{array}$ \\
\hline Nicola & Germany & 1962 & Clivia $\times 64301011$ & $\ldots$ \\
\hline Red Pontiac & United States & 1938 & 1975 selection from Pontiac & $\ldots$ \\
\hline Ranger Russet & United States & 1991 & Butte $\times$ A-6595-3 & $\begin{array}{l}N y, N z \text { (Kerlan et al. 2011; Nie et al. 2012; } \\
\text { Rowley et al. 2015) }\end{array}$ \\
\hline Red Lady & Germany & 1994 & YP-86-150 × Velox & $\ldots$ \\
\hline Red Rascal & New Zealand & 1995 & Tekau $\times$ Desiree & $\ldots$ \\
\hline Royal Blue & The Netherlands & 1995 & Asterisk $\times$ VE 76-46 & $\ldots$ \\
\hline Ruby Lou & Australia & 1988 & Foxton $\times 69-32 \mathrm{~T} 4$ & $\ldots$ \\
\hline Russet Burbank & United States & 1894 & 1902 selection from Burbank & $\begin{array}{l}n y, n z \text {, putative } N d \text { (Kehoe and Jones 2016; } \\
\text { Kerlan et al. 2011; Nie et al. 2012; Rowley } \\
\text { et al. 2015) }\end{array}$ \\
\hline Sequoia & United States & 1939 & Green Mountain $\times$ Katahdin & $\ldots$ \\
\hline Shine & Australia & 1997 & Wauseon $\times$ Wilwash & $\ldots$ \\
\hline Toolangi Delight & Australia & 1986 & Norgleam $\times$ Kennebec & $\ldots$ \\
\hline White Star & Australia & 2006 & Gladiator $\times 91-158-6$ & $\ldots$ \\
\hline White Rose (= Delaware $)^{\mathrm{b}}$ & United States & 1893 & Selection from Jackson & $n y, n z$, putative $N d$ (Kehoe and Jones 2016) \\
\hline Wilwash & Australia & 1991 & Norgleam $\times$ Coliban & $\ldots$ \\
\hline Yukon Gold & Canada & 1981 & Norgleam $\times$ W5279-4 & $\begin{array}{l}N y, N z \text {, putative } N d \text { (Kehoe and Jones 2016; } \\
\text { Kerlan et al. 2011; Nie et al. 2012; Rowley } \\
\text { et al. 2015) }\end{array}$ \\
\hline
\end{tabular}

\footnotetext{
a Information sources about cultivars: ECPD (2017) for European cultivars, PANA (2017) for North American cultivars, and Tony Slater and Peter Dawson for Australian cultivars.

${ }^{\mathrm{b}}$ White Rose is called Delaware in Australia.
} 
times those of healthy sap controls. The polyclonal PVY antiserum used was from Loewe Biochemica.

Disease assessment. With primary PVY infection following sap inoculation of potato plants, ER was considered present when no virus was detected in inoculated or uninoculated leaves, or when no such detection occurred in young upper leaves after graft inoculation. LHR was considered present when local necrotic spot or ring lesions developed in inoculated leaves without any systemic infection of shoots or systemic symptom development. SHR started with the appearance of the same local necrotic lesions in inoculated leaves but infection then moved systemically to shoots. SHR was considered present when systemic symptoms of shoot necrosis (i.e., killing of individual shoots), entire plant death, necrotic stem streaking, petiole necrosis, or necrotic spots or rings developed. These symptoms were treated as SHR descriptors. Symptoms commonly associated with susceptibility in potato plants included local chlorotic blotches or rings in inoculated leaves, and systemic symptoms of mosaic, chlorotic spots or blotches, green rings, and vein banding. These symptoms were considered susceptibility descriptors. When typical SHR descriptors were present in association with one or more of these susceptibility descriptors, this combination of symptoms was considered to represent weaker SHR expression. Systemic veinal necrosis was an unreliable descriptor of SHR in potato plants because it occasionally developed (mostly in mild form) when all other necrotic symptom types were absent. Similarly, because systemic necrotic patch symptoms mostly developed in senescent older leaves and occurred with susceptible responses (mostly in mild form) as well as SHR, they, too, were treated as unreliable SHR descriptors. Leaf deformation, leaf drop, and severe stunting symptoms were in the same situation because, although they were more severe with SHR, they sometimes developed in its absence. With secondary infection, the symptom descriptors of SHR and susceptibility used were the same as those for primary systemic infection. Images illustrating examples of the SHR descriptors, susceptibility descriptors, and unreliable SHR descriptors are shown in Figures 1 and 2.

With both primary and secondary infection, the severity categories of SHR used for disease assessment were very severe $=$ shoot necrosis or entire plant death and necrotic stem streaking without any other systemic symptoms; severe $=$ shoot necrosis or entire plant death, and necrotic stem streaking with at least one of petiole necrosis and systemic necrotic spots or rings but without any mosaic, chlorotic spotting, or blotching, chlorosis, green rings, or vein banding; moderate $=$ shoot necrosis or entire plant death with or without necrotic stem streaking but with at least one of petiole necrosis or systemic necrotic lesions, and at least one of the susceptibility descriptors; weak = without shoot necrosis or entire plant death but with necrotic stem streaking, and at least one of petiole necrosis or necrotic lesions, and at least one of the susceptibility descriptors; and very weak $=$ shoot necrosis, plant death, and necrotic stem streaking entirely absent but at least one of petiole necrosis or systemic necrotic lesions with at least one of the susceptibility descriptors.

\section{Results}

Primary infection. With all three isolates, two cultivars always remained uninfected in inoculated and noninoculated leaves (Lady Crystl and Royal Blue) and three others always developed mild symptoms without any virus-induced necrosis (Banana, Kipfler,

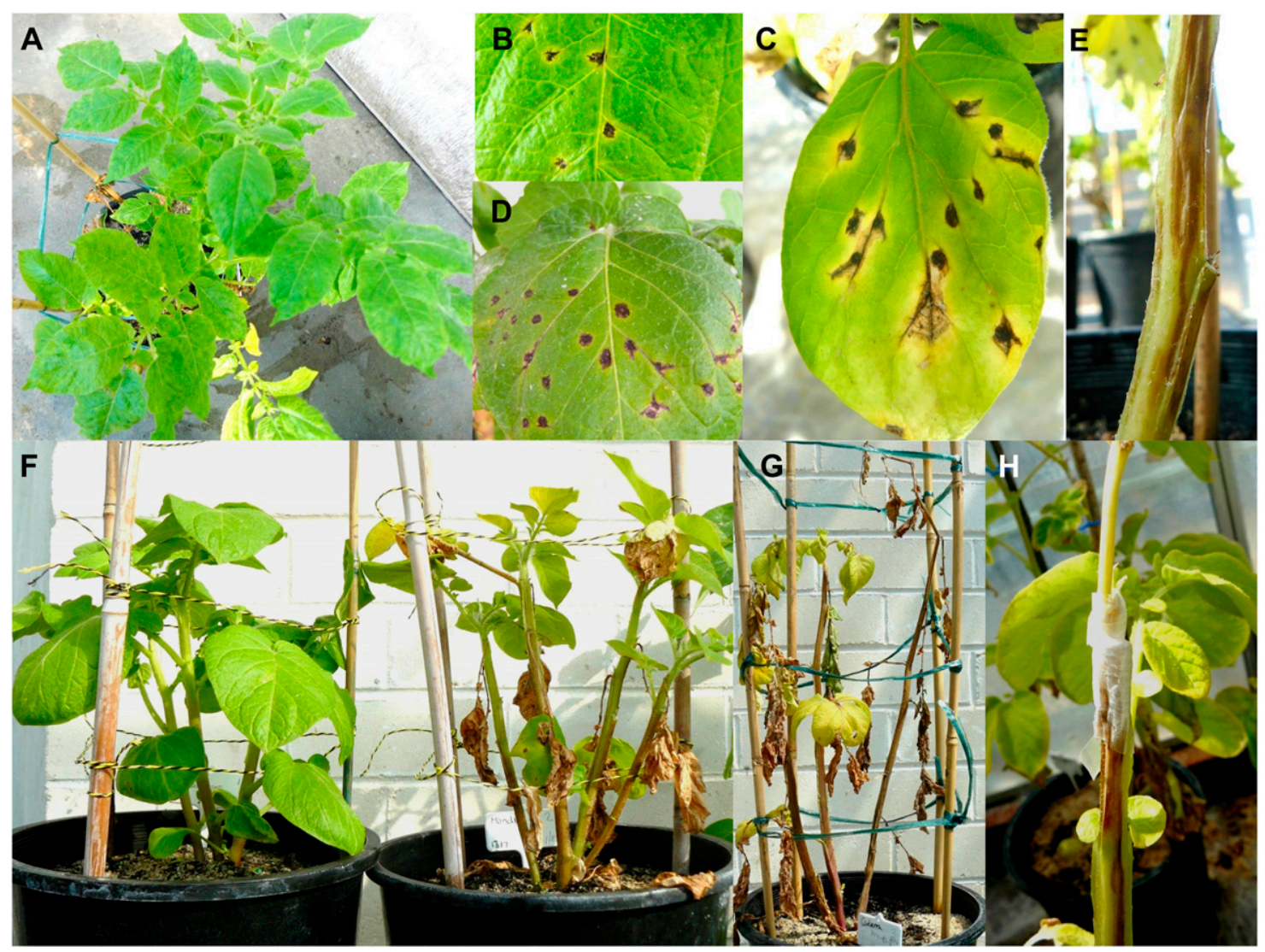

Fig. 1. Localized (LHR) and systemic (SHR) hypersensitive extreme resistance, extreme resistance (ER), or susceptible (S) phenotypes induced in the foliage of different potato cultivars following inoculation with three isolates of Potato virus Y. A, Mild mosaic symptoms (S) in leaves of a Kipfler plant caused by systemic infection following sap inoculation with isolate DEL3. B, Necrotic spot local lesions (LHR) in an inoculated leaf of White Rose caused by sap inoculation with isolate KIP1. C, Necrotic spot local lesions (LHR) in an inoculated leaf of Desiree caused by sap inoculation with isolate KIP1. D, Necrotic spot local lesions (LHR) in an inoculated leaf of Mondial caused by sap inoculation with isolate DEL3. E, Necrotic stem streaking symptoms (SHR) in a lower stem section of a Granola plant caused by systemic infection following sap inoculation with isolate BL. F, Plants of Mondial sap inoculated with isolate BL (right) or mock inoculated (left): infected plant on right shows systemic symptoms of necrotic stem streaking, petiole necrosis, and death of middle and lower leaves (SHR), whereas plant on left is healthy. G, Shoot necrosis and death, necrotic stem streaking, petiole necrosis, and leaf necrosis symptoms (SHR) in a plant of Canberra with systemic infection following sap inoculation with isolate BL. H, Symptoms of localized necrosis below the graft union without any virus spread elsewhere (ER) in a plant of Lady Crystl following graft inoculation with isolate DEL3. 
and MacRusset) (Tables 2 and 3; Fig. 1A). Therefore, the former exhibited ER and the latter susceptible phenotypes. With the 34 other cultivars, HR always developed with at least one isolate, and often with all three of them. Sometimes both LHR and SHR occurred together within the same PVY isolate-cultivar combination. When this happened, some inoculated plants had no shoots with systemic infection while others were systemically infected or, within the same plant, some shoots had systemic infection while others remained uninfected. Also, with isolate DEL3 in Dutch Cream and Yukon Gold potato, one or more types of SHR descriptor appeared only in some infected shoots but not others on the same plant.

Isolates BL and DEL3 both elicited susceptible phenotypes in 11 cultivars in addition to the three that developed a susceptible phenotype with all three isolates (Tables 2 and 3 ). This susceptible phenotype was mild with both isolates in seven cultivars (Bliss, FL2137, FL2204, FL2215, Innovator, Red Lady, and White Star) but severe with both isolates in one cultivar (Red Pontiac), BL alone in two (King Edward and Russet Burbank), and DEL3 alone in one (White Rose). By contrast, isolate KIP1 elicited HR not only in all of these 11 cultivars but also in all 23 others. This HR consisted of LHR alone in 31 of them (Fig. 1B and C) but a mixture of LHR and severe SHR in the other three (Atlantic, Desiree, and FL2204). Although isolates BL and DEL 3 both induced HR in the same 23 cultivars, they only elicited LHR alone in four (Almera, FL1867, Nadine, and Yukon Gold or two (FL1867 and FL2195), respectively. They elicited SHR alone in 15 (BL) and seven (DEL3) cultivars, and both LHR and SHR in four (BL) and 14 (DEL3) (Fig. 1D) other cultivars.
With isolate BL, SHR only fitted in the very severe category with Kestrel but Ruby Lou was also placed in this category as necrotic stem streaking was the only systemic symptom that developed and symptomless infection was absent (Table 2). Severe SHR was evident in 11 cultivars with isolate BL (Atlantic, Canberra, Desiree, Granola, Harmony, Lustre, Mondial, Nicola, Red Rascal, Shine, and Wilwash) (Fig. 1E, F, and G), and three with isolate DEL3 (Atlantic, Mondial, and Nadine). Moderate SHR occurred in five cultivars with BL (Dutch Cream, Maxine, Ranger Russet, Sequoia, and Toolangi Delight) and 12 with isolate DEL3 (Almera, Canberra, Desiree, Granola, Harmony, Kestrel, Maxine, Ranger Russet, Ruby Lou, Sequoia, Shine, and Yukon Gold). The weak SHR category contained no cultivars with isolate BL but two with isolate DEL3 (Dutch Cream and Wilwash). The very weak SHR category only included one cultivar with isolate BL (FL2195) and three with isolate DEL3 (Lustre, Nicola, and Toolangi Delight). Thus, isolate KIP1 consistently elicited the most severe SHR phenotypes on primary infection whereas, overall, SHR expression was weakest with isolate DEL3.

Secondary infection. As with primary infection, on secondary infection, the same three cultivars produced only a mild susceptible phenotype (Banana, Kipfler, and MacRusset) (Tables 2 and 3). Also, as with primary infection, isolates BL and DEL3 elicited a susceptible phenotype in the same 11 additional cultivars (Fig. 2A). This phenotype was mostly mild but severe mosaic developed with isolate BL in three cultivars (King Edward, Russet Burbank, and White Rose).

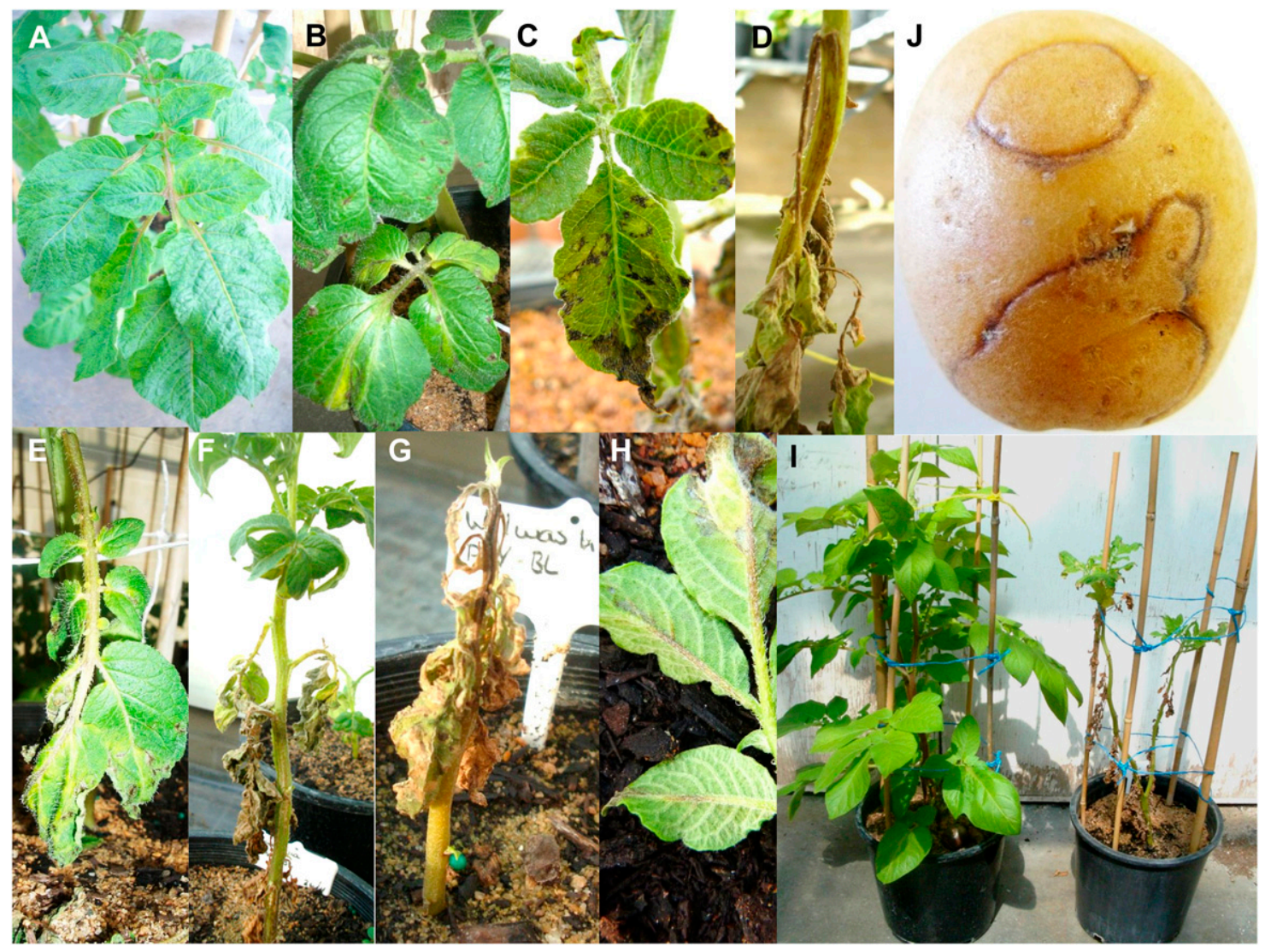

Fig. 2. Systemic hypersensitive resistance (SHR) or susceptible (S) phenotypes induced in foliage of different potato cultivars following secondary infection, or potato tuber necrotic ringspot disease (PTNRD) following primary infection, with two isolates of Potato virus Y. A, Mild mosaic (S) in a leaf of Red Lady caused by secondary infection with isolate BL. B. Systemic necrotic spotting (SHR) in a shoot of Ruby Lou caused by secondary infection with isolate BL. C, Systemic necrotic rings (SHR) and patches, blotchy mosaic, and leaf deformation symptoms in a leaf of Yukon Gold caused by secondary infection with isolate BL. D, Necrotic stem streaking, petiole necrosis (SHR), and leaf drop symptoms in a lower stem section of shoot of Mondial caused by secondary infection with isolate BL. E, Systemic necrotic spotting, petiole necrosis (SHR), and leaf drop symptoms in a leaf of Ruby Lou secondarily infected with isolate BL. F, Necrotic stem streaking, petiole necrosis, and leaf necrosis symptoms (SHR) in the lower section of a Sequoia shoot caused by secondary infection with isolate BL. G, Plant of Wilwash being killed (SHR) by secondary infection with isolate BL. H, Veinal necrosis and leaf deformation symptoms on the underside of a leaf from a Yukon Gold plant secondarily infected with isolate DEL3. I, Plants of Red Rascal secondarily infected with isolate DEL3 (right) or grown from a healthy tuber (left): infected plant on right shows symptoms of severe mosaic and leaf deformation in the few remaining uppermost leaves along with necrosis (SHR) and shedding of all other leaves, while plant on left is healthy. J, Necrotic rings (PTNRD) on the surface of a Nadine tuber caused by primary infection with isolate DEL3. 
Failure of tubers to pass on PVY from primarily infected mother plants to progeny plants occurred in isolate-cultivar combinations where (i) primary infection caused LHR alone, such that the rest of the plant was healthy so all the tubers were healthy, and (ii) severe SHR caused shoot or plant death, such that no tubers formed on infected plants, or tubers formed only on uninfected stems on plants in which only some stems were infected (Tables 2 and 3). However, in seven isolate-cultivar combinations where primary infection caused LHR alone, there was systemic PVY spread from inoculated leaves to underground stems despite no systemic virus infection

Table 2. Primary and secondary responses of 39 potato cultivars to sap inoculation with three isolates of Potato virus $Y(\mathrm{PVY})^{\mathrm{a}}$

\begin{tabular}{|c|c|c|c|c|c|c|}
\hline \multirow[b]{3}{*}{ Cultivar } & \multicolumn{6}{|c|}{ Isolate $^{b}$} \\
\hline & \multicolumn{3}{|c|}{ Primary symptoms } & \multicolumn{3}{|c|}{ Secondary symptoms } \\
\hline & KIP1 & BL & DEL3 & KIP1 & BL & DEL3 \\
\hline$\overline{\text { Almera }}$ & LNS, NS & LNS, NS & $\begin{array}{l}\text { LNS, NS or LNS, } \\
\text { SNS, VN, SGR, } \\
\text { LDR, NSST, PN, } \\
\text { SNc,d }^{\mathrm{c}, \mathrm{d}}\end{array}$ & NI & $\begin{array}{l}\text { NI or SM, LD, LDR, } \\
\text { SNS, SNP, VN }\end{array}$ & $\begin{array}{l}\text { NI or SCB, SM, LD, } \\
\text { LDR, SNS, SNP, } \\
\text { VN, PN, St }\end{array}$ \\
\hline Atlantice & $\begin{array}{l}\text { LNS, NS or LNS, } \\
\text { NSST, SN } \text { SN }^{c}\end{array}$ & $\begin{array}{l}\text { LNS, SNS, LDR, } \\
\text { NSST, PN, SN }\end{array}$ & $\begin{array}{l}\text { LNS, NS or LNS, } \\
\text { SNS, VN, LDR, } \\
\text { NSST, PN, SNc }\end{array}$ & $\begin{array}{l}\text { SM, LD, LDR, } \\
\text { SNS, SNP, VN, } \\
\text { NSST, PN, SN }\end{array}$ & $\begin{array}{l}\text { SM, LD, LDR, (SNS, } \\
\text { VN) }\end{array}$ & $\begin{array}{l}\text { M, LD, (SNS, SNP, } \\
\text { NSST) }\end{array}$ \\
\hline Banana $a^{e, f}$ & $\mathrm{MM}$ & MM, PSSLL & MM & $\mathrm{MM}$ & MM & MM \\
\hline Bliss ${ }^{e}$ & LNS, NS & LCB, LCR, MM & MM & NI & MM & MM \\
\hline Canberra & LNS, NS & $\begin{array}{l}\text { LNS, SNS, LDR, } \\
\text { NSST, PN, SN }\end{array}$ & $\begin{array}{l}\text { LNS, NS or LNS, SM, } \\
\text { LD, LDR, SNS, } \\
\text { SNR, VN, NSST, } \\
\text { PN, SNc }\end{array}$ & NI & $\begin{array}{l}\text { SM, LD, LDR, SNS, } \\
\text { VN, PN, NSST, } \\
\text { (PD) }\end{array}$ & $\begin{array}{l}\text { NI or SM, LD, LDR, } \\
\text { SNS, SNP, VN, } \\
\text { NSST }\end{array}$ \\
\hline Desiree $^{e}$ & $\begin{array}{l}\text { LNS, NS or LNS, } \\
\text { NSST }^{c}\end{array}$ & $\begin{array}{l}\text { LNS, NS or LNS, } \\
\text { SNS, NSST, PN, } \\
\text { SN }^{c}\end{array}$ & $\begin{array}{l}\text { LNS, NS or LNS, SM, } \\
\text { LD, LDR, SNS, VN, } \\
\text { NSST, PN, SNc }\end{array}$ & $\begin{array}{l}\text { NI or SNS, SNP, } \\
\text { VN, LDR, } \\
\text { NSST, PN or } \\
\text { SN }^{c}\end{array}$ & $\begin{array}{l}\text { SM, LD, LDR, SNS, } \\
\text { VN, (NSST), PN, } \\
\text { PD }\end{array}$ & $\begin{array}{l}\text { SM, LD, LDR, SNS, } \\
(\text { SNP, VN, NSST })\end{array}$ \\
\hline Dutch Cream & LNS, NS & $\begin{array}{l}\text { LNS, SCB, SM, } \\
\text { LD, LDR, SNS, } \\
\text { SNR, SNP, VN, } \\
\text { NSST, PN, SN }\end{array}$ & $\begin{array}{l}\text { LNS, LNR, SCB, M, } \\
\text { LD, VN, SNS, SNP, } \\
\text { LDR, (NSST), PN }\end{array}$ & NI & $\begin{array}{l}\text { SCB, M, LD, LDR, } \\
(\text { SNS, VN) }\end{array}$ & $\begin{array}{l}\text { SCB, SM, LD, LDR, } \\
(\text { SNS, SNP), VN }\end{array}$ \\
\hline FL1867 & LNS, NS & LNS, NS & LNS, NS & NI & NI & NI \\
\hline FL 2137 & LNS, NS & SS, MM & $\mathrm{MM}, \mathrm{VN}$ & NI & MM & MM \\
\hline FL2195 & LNS, NS & $\begin{array}{l}\text { LNS, NS or LNS, } \\
\text { SCB, SM, LD, } \\
\text { LDR SGR, SNS, } \\
\text { SNR, SNP, VN, } \\
\text { PNc }^{\mathrm{c}}\end{array}$ & LNS, NS & NI & $\begin{array}{l}\text { NI or SM, LD, LDR, } \\
\text { SNS, SNP, VN, } \\
\text { NSST, SSt }, \text { d }\end{array}$ & NI \\
\hline FL2204 & $\begin{array}{l}\text { LNS, NS or LNS, } \\
\text { NSST, } \text { SN }^{c}\end{array}$ & $\mathrm{MM}, \mathrm{VN}$ & LCB, MM, MVN & NI & MM, LD & M \\
\hline FL2215 & LNS, NS & MM & MM & NI & MM & - \\
\hline Granola & NLS, NS & $\begin{array}{l}\text { LNS, NS or LNS, } \\
\text { LDR, SNS, VN, } \\
\text { NSST, PN, } \\
\text { SNc }^{c}\end{array}$ & $\begin{array}{l}\text { LNS, NS or LNS, SM, } \\
\text { LD, LDR, SGR, } \\
\text { SNS, VN, NSST, } \\
\text { SNc }^{\text {c }}\end{array}$ & $\begin{array}{l}\text { LDR, SNS, SNR, } \\
\text { SNP, VN, NSST, } \\
\text { PN, SN }\end{array}$ & NI & NI \\
\hline Harmony & LNS, NS & $\begin{array}{l}\text { LNS, LDR, } \\
\text { NSST, PN, SN }\end{array}$ & $\begin{array}{l}\text { LNS, NS or LNS, SM, } \\
\text { LD, LDR, SNS, VN, } \\
\text { PN, SNc }\end{array}$ & $\begin{array}{l}\text { NI or NSST, PN, } \\
\text { SN }^{\mathrm{c}}\end{array}$ & $\begin{array}{l}\text { SVB, SM, LD, LDR, } \\
\text { SNS, SNR, SNP, } \\
\text { VN, NSST, PN, PD }\end{array}$ & $\begin{array}{l}\text { SCB, M, MLD, LDR, } \\
\text { (SNS, SNP, VN, } \\
\text { NSST) } \\
\text { (continued on next page) }\end{array}$ \\
\hline
\end{tabular}

a Numbers of plants inoculated were two to six (KIP1) or three to six (BL and DEL13) for each isolate-cultivar combination. Two to four plants of each cultivar were also mock inoculated with healthy sap. The plants were kept for 2 to 3 months after inoculation, when the tubers were harvested. Five to six tubers from infected plants were planted for each isolate-cultivar combination. Progeny plants were kept for 3 months after inoculation. For inoculated plants, samples from inoculated and noninoculated upper leaves were tested for PVY presence by ELISA after 3 to 6 and 4 to 10 weeks, respectively. For plants grown from tubers, samples from noninoculated upper leaves were tested for PVY presence by ELISA after 4 to 10 weeks. No virus was ever detected in mock-inoculated plants.

${ }^{\mathrm{b}}$ Response codes: $\mathrm{C}=$ chlorosis or pallor, FLNS $=$ faint local necrotic spots in inoculated leaves, $\mathrm{LCB}=$ local chlorotic blotches in inoculated leaves, $\mathrm{LD}=$ leaf deformation, $\mathrm{LDR}=$ leaf drop, $\mathrm{LNP}=$ local necrotic patches in inoculated leaves, $\mathrm{LNR}=$ local necrotic rings in inoculated leaves, $\mathrm{LNS}=$ local necrotic spots in inoculated leaves, $\mathrm{M}=$ mosaic, $\mathrm{MM}=$ mild mosaic, $\mathrm{MLD}=$ mild leaf deformation, $\mathrm{MVN}=$ mild veinal necrosis, $\mathrm{SM}=$ severe mosaic, $\mathrm{NI}=$ not infected (confirmed by ELISA testing), NS = not infected systemically, NSST = necrotic stem streaking, $\mathrm{PD}=$ plant death, $\mathrm{PN}=$ petiole necrosis, $\mathrm{PSSLL}=$ premature senescence and shedding of lower leaves, $\mathrm{SCB}=$ systemic chlorotic blotches, $\mathrm{SCS}=$ systemic chlorotic spots, $\mathrm{SGR}=$ systemic green rings, $\mathrm{SN}=$ systemic necrosis and shoot death, SNLP = systemic necrotic line patterns in inoculated leaves, SNP = systemic necrotic patches, SNR = systemic necrotic rings, $\mathrm{SNS}=$ systemic necrotic spots, $\mathrm{SS}=$ symptomless systemic infection, $\mathrm{SSt}=$ severe stunting, $\mathrm{SVB}=$ systemic vein banding, $\mathrm{VN}=$ veinal necrosis, $-=$ not tested, and ()$=$ symptoms only present in some shoots. Codes marked in bold: NI in bold indicates an extreme resistance response in Kipfler and Lady Crystl and a hypersensitivity response resulting in failure to pass infection via tubers to progeny plants with other cultivars; NS demonstrates a localized hypersensitive response resulting in failure of infection to spread systemically; SN, PD, and NSST demonstrate a systemic hypersensitivity response; and SNS, SNR, and PN constitute less important indicators of a systemic hypersensitive response.

${ }^{c}$ When systemic necrosis developed in this cultivar-isolate combination, some inoculated plants had no shoots with systemic infection whereas, in other inoculated plants, either all shoots had systemic infection or some shoots had systemic infection while other shoots were without any.

d Spread of infection delayed out of some tubers. Their symptoms were slow to appear but very necrotic.

e Abbreviated versions of the primary symptoms caused by isolates KIP1, BL, and DEL3 in these cultivars were reported previously (Kehoe and Jones 2016).

${ }^{\mathrm{f}}$ PVY-inoculated and mock-inoculated plants both developed nonviral leaflet necrosis, which was mostly marginal. 
being detected in foliage. This, in turn, resulted in some tubers becoming infected and producing progeny plants exhibiting SHR: it occurred with isolate KIP1 in four (Granola, Harmony, Nadine, and Shine) and isolate BL in three (Almera, Nadine, and Yukon Gold) cultivars but in none with DEL3. Progeny plants that were uninfected or exhibited SHR occurred together in 16 isolate-cultivar combinations: 4 with KIP1 (in Desiree, Harmony, Nadine, and Shine), 5 with BL (in Almera, FL2195, Nadine, Ruby Lou, and Yukon Gold), and 7 with DEL3 (Almera, Canberra, Lustre, Nicola, Red Rascal, Ruby Lou, and Yukon Gold). In three isolate-cultivar combinations

Table 2. (continued from previous page)

\begin{tabular}{|c|c|c|c|c|c|c|}
\hline \multirow[b]{3}{*}{ Cultivar } & \multicolumn{6}{|c|}{ Isolate $^{\text {b }}$} \\
\hline & \multicolumn{3}{|c|}{ Primary symptoms } & \multicolumn{3}{|c|}{ Secondary symptoms } \\
\hline & KIP1 & BL & DEL3 & KIP1 & BL & DEL3 \\
\hline$\overline{\text { Innovator }^{\mathrm{e}}}$ & LNS, NS & $\mathrm{MM}$ & $\mathrm{MM}$ & NI & $\mathrm{MM}$ & MM, MLD \\
\hline Kestrel & LNS, NS & $\begin{array}{l}\text { LNS, LDR, } \\
\text { NSST, SN }\end{array}$ & $\begin{array}{l}\text { LNS, NS or LNS, SM, } \\
\text { LD, LDR, SNS, } \\
\text { SNR, VN, NSST, } \\
\text { PN, SN }\end{array}$ & NI & NI & $\begin{array}{l}\text { SVB, SM, LD, LDR, } \\
\text { SNS, SNR, SNP, } \\
\text { VN, NSST, PN, SN }\end{array}$ \\
\hline King Edward ${ }^{\mathrm{e}}$ & FLNS, NS & SM, LD, PSSL & MM, LD, PSSL & NI & SM, LD & M, LD \\
\hline Kipflere,f & MM, PSSLL & MM, PSSLL & MM, PSSLL & MM & MM & MM \\
\hline Lady Crystl & NI & NI & NI & NI & NI & NI \\
\hline Lustre & LNS, NS & $\begin{array}{l}\text { LNS, LDR, VN, } \\
\text { NSST, PN, SN }\end{array}$ & $\begin{array}{l}\text { LNS, SM, LD, LDR, } \\
\text { SGR SNS, VN }\end{array}$ & NI & $\begin{array}{l}\text { SCS, SCB, LD, LDR, } \\
\text { SNS, SNR, VN, } \\
\text { NSST, PN, SSt }\end{array}$ & $\begin{array}{l}\text { NI or M, LD, LDR, } \\
(\text { SNS, SNP), VN }\end{array}$ \\
\hline MacRusset ${ }^{\mathrm{e}}$ & MM & SS & MM & MM, SS & MM, SS & MM \\
\hline Maxine & NLS, NS & $\begin{array}{l}\text { LNS, SCB, LDR, } \\
\text { SNS, NSST, PN, } \\
\text { SN }\end{array}$ & $\begin{array}{l}\text { LNS, NS or LNS, SM, } \\
\text { LD, LDR, SNS, VN, } \\
\text { PN, SN }\end{array}$ & NI & $\begin{array}{l}\text { SM, LD, LDR, (SNS, } \\
\text { VN, PN) }\end{array}$ & $\begin{array}{l}\text { SCB, SM, LD, LDR, } \\
\text { SNS, SNP, VN } \\
(\text { NSST) }\end{array}$ \\
\hline Mondial & LNS, NS & $\begin{array}{l}\text { LNS, LNR, LDR, } \\
\text { SNS, NSST, PN, } \\
\text { SN }\end{array}$ & $\begin{array}{c}\text { LNS, NS or LNS, } \\
\text { LDR, SNS, VN, } \\
\text { NSST, PN, SN }\end{array}$ & NI & $\begin{array}{l}\text { SM, LD, LDR, SNS, } \\
\text { SNR, VN, NSST, } \\
\text { PN, PD }\end{array}$ & $\begin{array}{l}\text { SCB, M, LD, LDR, } \\
\text { SNS, SNR, SNP, } \\
\text { VN, NSST, PN }\end{array}$ \\
\hline Nadine $\mathrm{e}^{\mathrm{e}}$ & LNS, NS & LNS, NS & $\begin{array}{l}\text { LNS, LNR, NS or } \\
\text { NSST, PN, SN }\end{array}$ & $\begin{array}{l}\text { NI or LD, SNS, } \\
\text { VN, NSST, PN, } \\
\text { SN or PD }\end{array}$ & $\begin{array}{l}\text { NI or LD, LDR, VN, } \\
\text { NSST, PN, } \mathbf{S N}^{\mathrm{c}, \mathrm{d}}\end{array}$ & $\begin{array}{l}\text { SM, LD, LDR, SNS, } \\
\text { SNP, VN, NSST, } \\
\text { PN, PD }\end{array}$ \\
\hline Nicola & LNS, NS & $\begin{array}{l}\text { LNS, LNR, LDR, } \\
\text { SNS, VN, NSST, } \\
\text { PN, SN }\end{array}$ & $\begin{array}{l}\text { LNS, SM, LD, SGR, } \\
\text { LDR, SNS, SNR, } \\
\text { VN, PN }\end{array}$ & NI & NI & $\begin{array}{l}\text { NI or SCB, SM, LD, } \\
\text { LDR, SNS, SNP, } \\
\text { VN, (NSST), PN }\end{array}$ \\
\hline Ranger Russet & LNS, SN & $\begin{array}{l}\text { LNS, LDR, SGR, } \\
\text { SNS, SNR, } \\
\text { NSST, SN }\end{array}$ & $\begin{array}{l}\text { LNS, NS or LNS, SM, } \\
\text { LD, LDR, SNS, } \\
\text { SNR, VN, NSST, } \\
\text { PN, SNc }\end{array}$ & NI & $\begin{array}{l}\text { SM, LD, LDR, SNS, } \\
\text { VN, NSST, PN, PD }\end{array}$ & $\begin{array}{l}\text { SCB, SM, LD, LDR, } \\
\text { SNS, SNP, VN, PN, } \\
\text { SSt }\end{array}$ \\
\hline Red Lady & LNS, NS & MM, PSSLL & LCB, MM, PSSLL & NI & MM or SS & MM, MLD \\
\hline Red Pontiac & LNS, NS & SM, LD, PSSLL & LCB, SM, LD & NI & M, LD & M, LD \\
\hline Red Rascal & LNS, NS & $\begin{array}{l}\text { LNS, LDR, SNS, } \\
\text { VN, NSST, PN, } \\
\text { SN }\end{array}$ & $\begin{array}{l}\text { LNS, NS or LNS, SM, } \\
\text { LDR, SNS, VN, } \\
\text { NSST, PN, SN }\end{array}$ & NI & $\begin{array}{l}\text { SM, LD, LDR, SNS, } \\
\text { VN, NSST, PN, PD }\end{array}$ & $\begin{array}{l}\text { NI or SCB, SM, LD, } \\
\text { LDR, VN, SNS, } \\
\text { SNP, (NSST), PN, } \\
\text { SN }\end{array}$ \\
\hline Royal Blue & NI & NI & NI & NI & - & NI \\
\hline Ruby Lou & LNS, NS & LNS, LDR, NSST & $\begin{array}{c}\text { LNS, NS or LNS, } \\
\text { MM, LD, LDR, } \\
\text { SNS, SNR, VN, } \\
\text { NSST, PN, SNc }\end{array}$ & NI & $\begin{array}{c}\text { NI or SCB, SM, LD, } \\
\text { LDR, SNS, SNR, } \\
\text { VN, NSST, PN, PD }\end{array}$ & $\begin{array}{l}\text { NI or LDR, SNS, } \\
\text { SNP, VN, NSST, } \\
\text { PN, SN }\end{array}$ \\
\hline Russet Burbank ${ }^{\mathrm{e}}$ & LNS, NS & SM, LD, PSSLL & MM & NI & SCB, SM, LD, PSSLL & M, MLD \\
\hline Sequoia & LNS, NS & $\begin{array}{l}\text { LNS, SCB, LDR, } \\
\text { SGR, SNS, SNR, } \\
\text { VN, NSST, PN, } \\
\text { SN }\end{array}$ & $\begin{array}{l}\text { LNS, SM, LD, LDR, } \\
\text { SNS, VN, NSST, } \\
\text { PD }^{\text {d }}\end{array}$ & NI & $\begin{array}{l}\text { SCB, SCS, LD, LDR, } \\
\text { SNS, VN, NSST, } \\
\text { PN, (SSt or PD) }\end{array}$ & $\begin{array}{l}\text { SCB, M, LD, LDR } \\
\text { (SNS, SNP, VN, } \\
\text { NSST) }\end{array}$ \\
\hline Shine & LNS, NS & $\begin{array}{l}\text { LNS, NS or LNS, } \\
\text { LDR, SNS, VN, } \\
\text { NSST, PN, } \\
\text { SNc }^{c}\end{array}$ & $\begin{array}{l}\text { LNS, NS or LNS, SM, } \\
\text { LD, LDR, SNS, } \\
\text { SNR, VN, NSST, } \\
\text { PN, SNc }\end{array}$ & $\begin{array}{l}\text { NI or SNS, } \\
\text { PN, SN }\end{array}$ & $\begin{array}{l}\text { SCS, LD, LDR, SNS, } \\
\text { VN, NSST, PD }\end{array}$ & $\begin{array}{c}\text { SM, LD, LDR, SNS, } \\
\text { SNP, VN, PN, SSt }\end{array}$ \\
\hline Toolangi Delight & FLNS, NS & $\begin{array}{l}\text { LNS, SCB, SM, } \\
\text { LD, LDR, SGR, } \\
\text { SNS, SNR, SNP, } \\
\text { VN, PN, SN }\end{array}$ & $\begin{array}{l}\text { LNS, SM, LD, LDR, } \\
\text { SGR SNS, VN }\end{array}$ & NI & - & $\begin{array}{l}\text { SCB, M, VB, MLD, } \\
\text { LDR, SGR, (VN, } \\
\text { SNS, SNP) }\end{array}$ \\
\hline White Rose ${ }^{e}$ & LNS, NS & $\begin{array}{l}\text { MM, LD, (VN), } \\
\text { PSSL }\end{array}$ & SM, LD, PSSLL & NI & SM, LD & MM, LD \\
\hline White Star & LNS, NS & SS & $\mathrm{LCB}, \mathrm{SS}$ & NI & M, LD, PSST & $\mathrm{M}, \mathrm{LD}$ \\
\hline Wilwash & LNS, NS & $\begin{array}{l}\text { LNS, LDR, SNS, } \\
\text { VN, NSST, PN, } \\
\text { SN }\end{array}$ & $\begin{array}{l}\text { LNS, MM, LDR, } \\
\text { SGR, SNS, SNR, } \\
\text { SNLP, VN, NSST }\end{array}$ & NI & $\begin{array}{l}\text { SCB, SM, LD, LDR, } \\
\text { SNS, VN, NSST, } \\
\text { PN, PD }\end{array}$ & $\begin{array}{l}\text { SCB, SM, LD, LDR, } \\
\text { SNS, SNR, VN, PD }\end{array}$ \\
\hline Yukon Golde & LNS, NS & LNS, NS & $\begin{array}{l}\text { LNS, LDR, C, LDR, } \\
\text { (SNS, SNR, VN), } \\
\text { NSST, PN, SN }\end{array}$ & NI & $\begin{array}{l}\text { NI or SCB, SM, LD, } \\
\text { LDR, SNS, SNR, } \\
\text { SNP, VN, NSST, } \\
\text { PN, PD }\end{array}$ & $\begin{array}{l}\text { NI or SCS, M, LD, } \\
\text { LDR, SNS, SNR, } \\
\text { VN, SGR, PN, PD }\end{array}$ \\
\hline
\end{tabular}


(isolate BL in Almera, FL 2195, and Nadine), infection was slow to spread from tubers of primarily infected to progeny plants. In addition, on secondary infection with isolates BL and DEL3, SHR symptom descriptors appeared in some infected shoots but not others with symptoms in more isolate-cultivar combinations than with primary infection.

With isolate KIP1, all progeny plants were healthy in 28 cultivars, two cultivars developed SHR alone, and four had some healthy shoots while their other shoots developed SHR (Tables 2 and 3). The corresponding figures for progeny plants that were entirely healthy, had SHR alone, or had some healthy plants or shoots were 4,13 , and 5 for isolate BL and 3, 13, and 7 for isolate DEL3, respectively. No isolate-cultivar combinations fitted the very severe SHR category on secondary infection. The severe category occurred with isolates KIP1 and BL in Nadine and KIP1 alone in four other cultivars (Desiree, Granola, Harmony, and Shine) but in none involving isolate DEL3; isolate KIP1 in Shine was included here despite the absence of necrotic stem streaking because no susceptibility descriptors were present. The moderate category included one isolate-cultivar combination with isolate KIP1 (in Atlantic), 11 with BL (in Canberra, Desiree, Harmony, Mondial, Ranger Russet, Red Rascal, Ruby Lou, Sequoia, Shine, Wilwash, and Yukon Gold) (Fig. 2B to G), and six with DEL3 (in Kestrel, Nadine, Red Rascal, Ruby Lou, Wilwash, Yukon Gold) (Fig. 2H and I). The weak category included no isolatecultivar combinations with isolate KIP1, two with BL (FL 2195 and Lustre), and eight with DEL3 (Atlantic, Canberra, Desiree, Harmony, Maxine, Mondial, Nicola, and Sequoia). The very weak category occurred with isolates BL and DEL3 in two (Almera and Dutch Cream), BL in two (Atlantic and Maxine), and DEL3 in four (Lustre, Ranger Russet, Shine, and Toolangi Delight) cultivars. Thus, isolate KIP1 consistently elicited the most severe HR phenotypes on secondary infection while SHR expression was weakest with isolate DEL3. Also, overall, SHR expression was weaker with secondary than primary infection.

Deductions from cultivar phenotypic responses. The inoculations to the key PVY differentials Desire and King Edward were repeated several times but doing this with every cultivar was unnecessary. This was because the phenotypes induced by $\mathrm{PVY}^{\mathrm{D}}$ isolate KIP1 in the 39

Table 3. Summary of phenotypic responses in plants of 39 potato cultivars to primary and secondary infection with three Australian Potato virus Y (PVY) isolates ${ }^{\text {a }}$

\begin{tabular}{|c|c|c|c|c|c|c|c|}
\hline \multirow[b]{3}{*}{ Cultivar } & \multicolumn{6}{|c|}{ Isolate } & \multirow[b]{3}{*}{ Resistance gene: } \\
\hline & \multicolumn{3}{|c|}{ Primary symptoms } & \multicolumn{3}{|c|}{ Secondary symptoms } & \\
\hline & KIP1 & BL & DEL3 & KIP1 & BL & DEL3 & \\
\hline Almera & LHR & LHR & LHR \& SHR & NI & NI \& (SHR) & NI \& (SHR) & Putative $N d: N y$ \\
\hline Atlantic ${ }^{b}$ & LHR \& SHR & SHR & LHR \& SHR & SHR & (SHR) & (SHR) & Putative $N d: N y$ \\
\hline Banana $^{b}$ & $\mathrm{~S}$ & $\mathrm{~S}$ & $\mathrm{~S}$ & $\mathrm{~S}$ & $\mathrm{~S}$ & $\mathrm{~S}$ & $n d: n y$ \\
\hline Bliss ${ }^{b}$ & LHR & $\mathrm{S}$ & $\mathrm{S}$ & NI & $\mathrm{S}$ & $\mathrm{S}$ & Putative $N d: n y$ \\
\hline Canberra & LHR & SHR & LHR \& SHR & NI & SHR & NI \& (SHR) & Putative $N d: N y$ \\
\hline Desiree $^{b}$ & LHR \& SHR & LHR \& SHR & LHR \& SHR & NI \& SHR & SHR & (SHR) & Putative $N d: N y$ \\
\hline Dutch Cream & LHR & SHR & (SHR) & NI & (SHR) & (SHR) & Putative $N d: N y$ \\
\hline FL1867 & LHR & LHR & LHR & NI & NI & $\mathrm{NI}$ & Putative $N d: N y$ \\
\hline FL2137 & LHR & $\mathrm{S}$ & $\mathrm{S}$ & NI & $\mathrm{S}$ & $\mathrm{S}$ & Putative $N d: n y$ \\
\hline FL2195 & LHR & LHR \& (SHR) & LHR & NI & NI or (SHR) & NI & Putative $N d: N y$ \\
\hline FL2204 & LHR \& SHR & $\mathrm{S}$ & $\mathrm{S}$ & NI & $\mathrm{S}$ & $\mathrm{S}$ & Putative $N d$ : $n y$ : \\
\hline FL2215 & LHR & $\mathrm{S}$ & $\mathrm{S}$ & NI & $\mathrm{S}$ & $\mathrm{S}$ & Putative $N d: n y$ \\
\hline Granola & LHR & LHR \& SHR & LHR \& SHR & SHR & NI & NI & Putative $N d: N y$ \\
\hline Harmony & LHR & SHR & LHR \& SHR & NI \& SHR & SHR & (SHR) & Putative $N d: N y$ \\
\hline Innovator & LHR & $\mathrm{S}$ & $\mathrm{S}$ & NI & $\mathrm{S}$ & $\mathrm{S}$ & Putative $N d: n y$ \\
\hline Kestrel & LHR & SHR & LHR \& SHR & NI & NI & SHR & Putative $N d: N y$ \\
\hline King Edward ${ }^{\mathrm{b}}$ & LHR & $\mathrm{S}$ & $\mathrm{S}$ & $\mathrm{NI}$ & $\mathrm{S}$ & $\mathrm{S}$ & Putative $N d: n y$ \\
\hline Kipfler $^{b}$ & $\mathrm{~S}$ & $\mathrm{~S}$ & $\mathrm{~S}$ & $\mathrm{~S}$ & $\mathrm{~S}$ & $\mathrm{~S}$ & $n d: n y$ \\
\hline Lady Crystl & ER & ER & ER & NI & NI & NI & $R y$ \\
\hline Lustre & LHR & SHR & (SHR) & NI & (SHR) & NI \& (SHR) & Putative $N d: N y$ \\
\hline MacRusset $^{\mathrm{b}}$ & $\mathrm{S}$ & $\mathrm{S}$ & $\mathrm{S}$ & $\mathrm{S}$ & $\mathrm{S}$ & $\mathrm{S}$ & $n d: n y$ \\
\hline Maxine & LHR & SHR & LHR \& SHR & NI & (SHR) & (SHR) & Putative $N d: N y$ \\
\hline Mondial & LHR & SHR & LHR \& SHR & NI & SHR & $(\mathrm{SHR})$ & Putative $N d: N y$ \\
\hline Nadine $^{b}$ & LHR & LHR & LHR \& SHR & NI \& SHR & NI \& SHR & SHR & Putative $N d: N y$ \\
\hline Nicola & LHR & SHR & $(\mathrm{SHR})$ & $\mathrm{NI}$ & $\mathrm{NI}$ & NI \& (SHR) & Putative $N d: N y$ \\
\hline Ranger Russet & LHR & SHR & LHR \& SHR & NI & SHR & (SHR) & Putative $N d: N y$ \\
\hline Red Lady & LHR & $\mathrm{S}$ & $\mathrm{S}$ & NI & $\mathrm{S}$ & $\mathrm{S}$ & Putative $N d: n y$ \\
\hline Red Pontiac & LHR & $\mathrm{S}$ & $\mathrm{S}$ & NI & $\mathrm{S}$ & $\mathrm{S}$ & Putative $N d: n y$ \\
\hline Red Rascal & LHR & SHR & LHR \& SHR & NI & SHR & NI \& SHR & Putative $N d: N y$ \\
\hline Royal Blue & ER & ER & ER & NI & - & $\mathrm{NI}$ & $R y$ \\
\hline Ruby Lou & LHR & SHR & LHR \& SHR & NI & NI \& SHR & NI \& SHR & Putative $N d: N y$ \\
\hline Russet Burbank ${ }^{b}$ & LHR & $\mathrm{S}$ & $\mathrm{S}$ & NI & $\mathrm{S}$ & $\mathrm{S}$ & Putative $N d: n y$ \\
\hline Sequoia & LHR & SHR & SHR & NI & SHR & (SHR) & Putative $N d: N y$ \\
\hline Shine & LHR & LHR \& SHR & LHR \& SHR & NI \& SHR & SHR & (SHR) & Putative $N d: N y$ \\
\hline Toolangi Delight & LHR & SHR & (SHR) & $\mathrm{NI}$ & - & (SHR) & Putative $N d: N y$ \\
\hline White Rose ${ }^{b}$ & LHR & $\mathrm{S}$ & $\mathrm{S}$ & NI & $\mathrm{S}$ & $\mathrm{S}$ & Putative $N d: n y$ \\
\hline White Star & LHR & $\mathrm{S}$ & $\mathrm{S}$ & NI & $\mathrm{S}$ & $\mathrm{S}$ & Putative $N d: n y:$ \\
\hline Wilwash & LHR & SHR & (SHR) & NI & SHR & SHR & Putative $N d: N y$ \\
\hline Yukon Gold ${ }^{\mathrm{b}}$ & LHR & LHR & SHR & $\mathrm{NI}$ & NI \& SHR & NI \& SHR & Putative $N d: N y$ \\
\hline
\end{tabular}

a Summary of resistance or susceptibility responses in potato plants inoculated with different PVY isolates and in plants grown from tubers harvested from the inoculated plants tubers. Coded responses: ER = extreme resistance; LHR = localized hypersensitive response, no spread out of inoculated leaves; SHR = systemic hypersensitive response, very severe to moderate categories; $\mathrm{S}=$ systemic susceptible response; (SHR) = systemic hypersensitive response, weak to very weak categories; NI = not infected (confirmed by enzyme-linked immunosorbent assay testing); and $-=$ not tested

${ }^{b}$ Resistance or susceptibility responses elicited by primary infection in these cultivars reported previously in summarized form without information on severity of symptom expression (Kehoe and Jones 2016). 
cultivars inoculated were always very clear, the vast majority developing obvious LHR on primary infection followed by lack of any secondary infection (Tables 2 and 3), a few developing severe or very severe SHR followed by lack of secondary infection or severe secondary (+ a single moderate) SHR, three developing susceptible phenotypes (mosaics) in both primary and secondary infection, and two developing ER. Also, with PVYO isolates BL and DEL3, whether the primary and secondary phenotypes were HR, susceptible, or ER always coincided for each cultivar, although SHR was generally more severe with BL than DEL3.

The results revealed that phenotype ER occurred when all three PVY isolates infected two recent European potato cultivars (Lady Crystl and Royal Blue) but none from Australasia or North America (Tables 1, 2, and 3). Also, isolate KIP1 elicited a susceptible phenotype in a single recent cultivar from Australasia (MacRusset) and two very old (pre-1925) fingerling-type European cultivars (Banana and Kipfler) but an HR phenotype in all 34 others tested regardless of age or region of origin; for example, the cultivars responding to KIP1 with HR ranged from two very old North American ones released in 1893 to 1894 (Russet Burbank and White Rose) to the most recent cultivar tested, which was released in Europe in 2010 (Canberra). With isolates BL and DEL3, HR phenotypes developed in 23 cultivars, being widespread among Australasian, European, and North American ones. The oldest cultivars responding with HR to infection with these two isolates were a North American one released in 1939 (Sequoia) and a European cultivar from 1962 (Nicola), whereas the newest to respond with HR was one released in Europe in 2010 (Canberra). Six of the newer cultivars that developed HR with these two isolates also had a parent that developed HR in this study. This parent was Australasian Wilwash (for Australasian Lustre and Shine), North American Atlantic (for North American FL1867), European Desiree (for Australasian Red Rascal), Nicola (for Australian Dutch Cream), and Nadine (for European Harmony) (Tables 1 and 3). In addition, European Cara and Foxton and North American Katahdin, previously reported to respond with $\mathrm{HR}$ after inoculation with different $\mathrm{PVY}^{\mathrm{O}}$ isolates (Jones 1990), were parents of European Kestrel, Australasian Ruby Lou, or North American Sequoia, respectively. Furthermore, North American Norgleam was a parent of Australian Toolangi Delight and Wilwash and of North American Yukon Gold, all of which responded with HR following infection with the two PVYO isolates, and Yukon Gold has Katahdin as a grandparent (Kerlan et al. 2011).

PTNRD symptoms in tubers. No symptoms of PTNRD were found in any tubers from plants primarily or secondarily infected with isolate KIP1. However, obvious necrotic ring symptoms were found occasionally among the tubers harvested from the infected plants of five cultivars. For tubers from primarily infected plants, the cultivar-isolate combinations were Almera (one tuber/cultivar), Harmony (two tubers/cultivar), and Ranger Russet (one tuber/cultivar) with isolate BL, and Nadine (three tubers/cultivar) with isolate DEL3 (Fig. 2J). The corresponding findings with tubers from secondarily infected plants were Nadine (two tubers/cultivar) and Yukon Gold (one tuber/cultivar) with BL but none with DEL3.

Graft inoculation. Graft-inoculated plants of Lady Crystl with isolate DEL3, and of Innovator and MacRusset with isolate BL, were the only virus-host combinations in which symptoms developed. In Lady Crystl with DEL3, localized necrosis developed just below the graft union without spreading any further (Fig. 1H). This phenotype involving localized necrosis below the graft union without further spread of infection was found with ER phenotypes previously (Jones 1990). Mild mosaic developed in Innovator and MacRusset with BL. PVY was detected in upper leaves of Innovator and MacRusset with BL but never in any other graft-inoculated plants, including the control plants of these two cultivars and of Lady Crystl and Royal Blue.

\section{Discussion}

This article revealed, for the first time, the widespread occurrence among potato cultivars of HR elicited by infection with strain group $\mathrm{PVY}^{\mathrm{D}}$ in the presence of putative hypersensitivity gene $N d$. This phenotype occurred in 34 of the 39 cultivars released between 1893 and 2010 in Australasia, Europe, or North America, including two released as early as 1893 to 1894 in North America. Thus, putative gene $N d$ has been present but unrecognized since the earliest era of potato breeding in the second half of the 19th century (Glendinning 1983). Our study also revealed the widespread occurrence of HR elicited by strain group $\mathrm{PVY} \mathrm{Y}^{\mathrm{O}}$ in the presence of hypersensitivity gene $N y$. This phenotype was present in 23 of the same 34 potato cultivars with putative $N d$, occurring widely among cultivars released between 1939 and 2010 in each of the three world regions. The HR elicited by our PVY ${ }^{\mathrm{D}}$ isolate in the presence of putative $N d$ was mostly LHR but, when SHR developed, its expression was mostly very severe or severe in primary or secondary infection, respectively. In contrast, the HR elicited by the two $\mathrm{PVY}^{\mathrm{O}}$ isolates in the presence of $N y$ was mostly SHR. On primary infection, it ranged from very severe with isolate $\mathrm{BL}$ and severe with isolate DEL3 to very weak with both isolates whereas, on secondary infection, it ranged from severe with BL and moderate with DEL3 to very weak with both isolates. PTNRD developed occasionally in tubers of five sensitive cultivars infected with these two isolates. With all three isolates, only one cultivar from North America always expressed LHR alone on primary infection followed by failure of PVY to spread to all progeny plants. Among the remaining five of the 39 cultivars studied, two (both European) developed only ER and three (two European and one Australasian) only susceptible phenotypes. Genes $R y, N y$, and putative $N d$ were all absent from the latter whereas, in the former, graft inoculations with all three isolates confirmed the ER phenotypes and, thus, the presence of $R y$. None of the cultivars developed the comprehensive hypersensitive phenotype associated with PVY genes $N y-1$ and $N y-2$. Eight older cultivars that responded with HR following inoculation with the two $\mathrm{PVY}^{\mathrm{O}}$ isolates, or after inoculation with other $\mathrm{PVY}^{\mathrm{O}}$ isolates in a previous study (Jones 1990), were parents of one or more cultivars that responded with $\mathrm{HR}$ after $\mathrm{PVY} \mathrm{O}^{\mathrm{O}}$ inoculation. These parents included North American Katahdin, which was released in 1932 and is the oldest cultivar known to carry $N y$. These findings have important implications concerning breeding new PVY-resistant potato cultivars, especially for countries lacking healthy seed potato stocks or where subsistence farmers cannot afford them. An alternative to including genes $R y \mathrm{Ny}-1$ or $\mathrm{Ny}-2$ is incorporating as many strainspecific PVY resistance genes as possible.

When combined with the presence of one or more of the four susceptibility descriptors used, employing our three major and two minor SHR descriptors proved an effective way to evaluate the severity of SHR expression within different PVY isolate-cultivar combinations. This was so with both primary and secondary SHR. Among the 34 cultivars that developed HR with the PVY isolate KIP1, HR consisted of LHR alone in all but three of them following primary infection, and expression of this SHR was always within the very severe or severe categories, and this was also so in five of the seven cultivars with SHR following secondary infection. With the two $\mathrm{PVY}^{\mathrm{O}}$ isolates, on primary and secondary infection expression of SHR was never in the weak or very weak categories in two cultivars from Australasia (Red Rascal and Ruby Lou), three from Europe (Granola, Kestrel, and Nadine), and one from North America (Yukon Gold) (Table 3). At the other end of the severity spectrum, SHR was always weak or very weak on primary and secondary infection with isolate DEL3 in four Australasian cultivars (Dutch Cream, Lustre, Shine, and Toolangi Delight). This was also so on secondary infection with isolate BL in two of the same Australasian cultivars (Dutch Cream, Lustre), with both isolates in three European cultivars (Almera, Maxine, and Mondial), and with isolate DEL3 in one European culti$\operatorname{var}$ (Nicola). The question arises as to why the severity of $\mathrm{PVY}^{\mathrm{O}}$ elicited SHR expression varies with isolate-cultivar combination. The gene-for-gene interaction between gene $N y$ in potato and helper component proteinase in PVY (Moury et al. 2011; Tian and Valkonen 2013) was influenced by both cultivar genetic background and $P V Y^{\mathrm{O}}$ isolate. For genetic background, the evidence for this was that, as judged by the occurrence of major and minor SHR descriptors in different isolate-cultivar combinations in both primary and secondary infection, some cultivars consistently developed severe SHR and others weaker SHR regardless of PVY isolate. For PVY isolates, the evidence for this is that, overall, isolate BL caused more severe SHR than isolate DEL3, especially on secondary infection. 
In the early days of plant virology, "leaf drop streak" was considered a characteristic symptom of primary infection with $\mathrm{PVY}^{\mathrm{O}}$ in potato plants, although it did not develop in all potato cultivars (Bawden and Kassanis 1947; de Bokx and Huttinga 1981; Murphy 1921; Smith 1957). This syndrome showed initially as blotchy mottle, necrotic spots, or rings and crinkling (i.e., deformation) in uppermost leaves followed by necrosis of veins on leaf undersides. This necrosis then spread to the petiole and, from there, to the main stem, producing necrotic stem streaking. Leaves below the uppermost ones became completely necrotic and withered but remained hanging as if attached to the stem by a thread while the symptomatic uppermost leaves remained alive. Tubers harvested from plants with this classic leaf drop streak syndrome typically produced progeny plants with milder secondary symptoms, showing less necrosis and leaf drop (Bawden and Kassanis 1947; de Bokx and Huttinga 1981; Murphy 1921; Smith 1931, 1957). Although our disease assessments did not include leaf drop and veinal necrosis among the SHR descriptors because these sometimes occurred in milder form where SHR was absent, the leaf drop streak syndrome corresponds with our weak SHR category (i.e., with necrotic stem streaking and at least one minor SHR descriptor and one susceptibility descriptor), while the secondary symptoms described for its progeny plants resembled our "very weak" SHR category. Interestingly, although its presence remained unknown at that time, observation of this classic $\mathrm{PVY}^{\mathrm{O}}$ symptom as early as 1921 (Murphy 1921; Smith 1931) suggests that $N y$ was present in cultivars bred at the beginning of the 20th century. Additional evidence for this comes from knowledge that North American Sequoia, released in 1939, carries $N y$ (Tables 1, 2, and 3), as does its parent Katahdin, released in 1932 (Davidson 1980; Hutton 1951; Jones 1990).

Why did both existence of strain group $\mathrm{PVY}^{\mathrm{D}}$ and widespread presence of putative gene $N d$ in potato cultivars remained unrecognized until recently? Ability of PVY isolate Rs118 from clone CPC188 to induce HR in all 17 of the British (mostly Scottish) potato cultivars or breeding lines inoculated with it, including ones which carried or lacked genes $N c$ or $N y$, was recorded 40 years ago (Davidson 1980; Davidson and Butzonitch 1978a,b). Assuming that isolate Rs118 belongs to strain group $\mathrm{PVY}^{\mathrm{D}}$, absence of any cultivars or breeding lines that developed susceptible phenotypes may have contributed to lack of recognition of this early research, because the susceptible phenotypes that develop with $\mathrm{PVY}^{\mathrm{D}}$ infection of three rarely tested minor cultivars, Australian MacRusset and two European fingerling cultivars (Banana and Kipfler) were only reported recently (Kehoe and Jones 2016; this study). However, three other factors are likely to have played more important roles. First, the very frequent occurrence of putative gene $N d$ in potato cultivars commonly grown in Australasia, Europe, and North America and its effectiveness in preventing build-up of $\mathrm{PVY}^{\mathrm{D}}$ due to the minimal tuberborne infection carry over associated with LHR or severe SHR primary infection phenotypes (Table 3). Second, the presence of putative $N d$ in both of the key differentials King Edward ( $N c: n y: n z$ :putative $N d$ ) and Desiree ( $n c: N y: n z$ :putative $N d$ ) used to distinguish strain group $\mathrm{PVY}^{\mathrm{C}}$ from $\mathrm{PVY} \mathrm{O}^{\mathrm{O}}$, such that $\mathrm{PVY}^{\mathrm{D}}$ inoculation to both of them elicits an HR phenotype. Third, when phylogroup $\mathrm{PVY}^{\mathrm{C}}$ isolates are found, they are normally assumed to belong to strain group $P V Y^{C}$ despite not being inoculated to potato cultivar differentials and recent knowledge that $\mathrm{PVY}^{\mathrm{D}}$ also resides in this phylogroup. Strain group $\mathrm{PVY}^{\mathrm{C}}$ isolates have recently become less common worldwide in potato (Karasev and Gray 2013a; Singh et al. 2008), although they were still found easily in potato the early 1980s in the United Kingdom (Jones 1990), and phylogroup PVYC nonpotato isolates are still found readily worldwide (Chikh-Ali et al. 2016; Green et al. in press; Kehoe and Jones 2016). An example of previous misdiagnosis arising from HR development in a cultivar with gene $N c$ was when Potato virus V(PVV; genus Potyvirus, family Potyviridae) was mistakenly placed within strain group $\mathrm{PVY}^{\mathrm{C}}$ because it gave an HR phenotype when inoculated to Dutch Gladblaadje potato (Calvert et al. 1980; de Bokx et al. 1975; Rozendal et al. 1971). It later transpired that, in addition to $N c$, Gladblaadje also carried hypersensitivity gene $N v$ elicited by PVV which, like putative gene $N d$, is present in the vast majority of potato cultivars (Jones 1987, 1990; Jones and Fribourg 1986; Jones and Fuller 1984).

In an earlier study, plants of European and Andean potato cultivars were sap and graft inoculated with PVY isolates belonging to strain groups PVY ${ }^{\mathrm{C}}, \mathrm{PVY}^{\mathrm{O}}, \mathrm{PVY}^{\mathrm{Z}}$, and $\mathrm{PVY}^{\mathrm{N}}$ (Jones 1990). Among the three Andean cultivars, one developed HR phenotypes consistent with the presence of genes $N c$ and $N y$, one an HR phenotype consistent with gene $N c$ alone, and one with neither; thus both genes were easily found in commercial cultivars in potato's original center of domestication (Jones 1981, 1990). The corresponding figures for the European cultivars were six with $N c$, six with $N y$, and one with neither. An HR phenotype consistent with $N z$ presence and an ER phenotype consistent with $R y$ presence developed in two cultivars each (Jones 1990). In the current study with 39 cultivars, sap and graft inoculation with three PVY isolates revealed $R y$ in two of the 21 European cultivars but in none from North America or Australasia. In a another recent study with 12 cultivars from Australia, Europe, or North America, HR phenotypes consistent with $\mathrm{Nz}$ presence were found in one cultivar each from Europe and North America (Kehoe and Jones 2016). Thus, $R y$ and $\mathrm{Nz}$ have been found less often and $N y$ and $N c$ more often, while putative gene $N d$ seems rarely absent. It would be interesting to establish how widespread resistance genes $R y, N c, N z, N y$, and putative $N d$ are among Andean potato cultivars and to what extent they protect Andean potato crops against PVY infection. This applies to both (i) Andean native potato land races growing in subsistence plantings and (ii) commercial plantings grown without access to healthy seed programs (Jones 1981). The question arises concerning whether the presence of genes $R y, N y$, and putative $N d$ has arisen by accident in commercial potato cultivars outside the Andes rather than by the deliberate intention to incorporate them into new cultivars by potato breeders. Because it provides comprehensive PVY resistance, $R y$ is the most attractive gene for breeders to use (Jones 1990; Solomon-Blackburn and Barker 2001; Valkonen et al. 1996). Its presence in two recent European cultivars in this study and two others in a previous study (Jones 1990) seems a direct consequence of breeding from parents with $R y$. By contrast, because its existence was only proposed recently (Kehoe and Jones 2016), the widespread occurrence of putative gene $N d$ in all except three of the 37 cultivars without $R y$ studied here reflects breeders unknowingly making crosses using parents with this gene. The same applies to gene $N y$ in the vast majority of cases but, in the $1970 \mathrm{~s}, \mathrm{PVY}^{\mathrm{O}}$ resistance was deliberately introduced into new cultivars by the Scottish Plant Breeding Station (Davidson 1980). The parents used in crosses were (i) Katahdin itself and (ii) Australian clone 11-79, which carries $N y$ and has Katahdin in its parentage (Hutton 1951). Katahdin originally came from a cross between USDA 40568 and USDA 2464 (PANA 2017). In both primary and secondary infection, the degree of $\mathrm{PVY} \mathrm{Y}^{\mathrm{O}}$ resistance conferred by $N y$ varies from cultivar to cultivar, depending on the extent of LHR or severe SHR versus weak SHR that develops. With LHR, when no systemic invasion occurs on primary infection and progeny plants from mother plants with LHR are healthy, the source of infection for further virus spread is removed. Moreover, when SHR involves death of all systemically infected shoots or entire plant death, foci of PVY infection are removed from within the crop and, thus, are unavailable to become infection sources for secondary spread. In contrast, weak SHR that allows PVY-infected plants to persist means that they can act as sources for secondary spread. Fortunately, early studies reported that planting new cultivars with gene $\mathrm{Ny}$ is more effective in the field than in inoculation tests (Davidson 1980) and, thus, still provides valuable $\mathrm{PVY}^{\mathrm{O}}$ field resistance (Jones 1987, 1990). A recent example of its effectiveness against $\mathrm{PVY}^{\mathrm{O}}$ in the field came from a study in a potato-growing region of North America following widespread planting of cultivars with $N y$. Over a 5-year period, incidence of $\mathrm{PVY}^{\mathrm{O}}$ dropped from 63 to $7 \%$ of the PVY population (Funke et al. 2017). Deployment of cultivars with $N y$ alone is likely to be especially useful in isolated potato-growing regions where $\mathrm{PVY}{ }^{\mathrm{O}}$ is still the only or predominant strain group present, and strain groups $\mathrm{PVY}^{\mathrm{C}}, \mathrm{PVY}^{\mathrm{N}}, \mathrm{PVY}^{\mathrm{Z}}$, and $\mathrm{PVY}^{\mathrm{E}}$, and the recombinant PVY strains that also overcome it are still rare or absent (e.g., southwest Australia) (Kehoe and Jones 2016). Although most parents used in breeding new potato cultivars already 
carry putative gene $N d$, breeding new cultivars without it should be avoided because otherwise $\mathrm{PVY} \mathrm{P}^{\mathrm{D}}$ is likely to invade them when gown in close proximity to cultivars without this gene.

In developed countries where sophisticated, healthy seed potato schemes operate and high-quality seed stocks are available, the focus of commercial plant breeding has tended to move away from breeding for virus resistance to focusing predominantly on other factors such as improved yield and tuber quality. However, in developing countries that lack supplies of healthy seed stocks, or where potato growers cannot afford to purchase them, there is still an urgent need for cultivars with effective virus resistance. When breeding new potato cultivars with PVY resistance for such countries, the next best option to inclusion of the ER provided by gene $R y$ or the comprehensive hypersensitive resistance provided by genes $\mathrm{Ny}-1$ and $\mathrm{Ny}-2$ is breeding cultivars with as many strain-specific PVY resistance genes as possible, such as Nadine and Yukon Gold (both $N y: N z$ :putative Nd) (Kehoe and Jones 2016; this study) or Cara, Maris Bard, and Pentland Ivory (all $N c: N y: N z$ ) (Jones 1990).

\section{Acknowledgments}

This research was undertaken using the glasshouse and laboratory facilities of the Department of Agriculture and Food Western Australia (DAFWA), and was funded by the Australian Produce Commission Potato Producers Committee, the University of Western Australia, and DAFWA. We thank D. Spencer and D. Tooke of DAFWA for provision of healthy seed potato tubers; the Victorian Department of Primary Industries, Toolangi Elite Ltd., and the University of Tasmania for supplying tissue cultured, virus-tested mini-tubers; P. Dawson and T. Slater for providing parentage and year of release data for Australasian potato cultivars; E. Gajda for help with sampling and testing leaf samples by ELISA; and B. Coutts and M. Kehoe for help with scoring plants for virus symptoms or taking photographs.

\section{Literature Cited}

Bald, J. G., and Norris, D. O. 1945. Virus C from an old Australian variety of potato. Phytopathology 35:591-597.

Barker, H., McGeachy, K. D., Toplak, N., Gruden, K., Zel, J., and Browning, I. 2009. Comparison of genomic sequences of PVY isolates with biological properties. Am. J. Potato Res. 86:227-238.

Bawden, F. C., and Kassanis, B. 1946. Varietal differences in susceptibility to potato virus Y. Ann. Appl. Biol. 33:46-50.

Bawden, F. C., and Kassanis, B. 1947. The behaviour of some naturally occurring strains of potato virus Y. Ann. Appl. Biol. 34:503-516.

Bawden, F. C., and Sheffield, F. M. L. 1944. The relationships of some viruses causing necrotic diseases of the potato. Ann. Appl. Biol. 31:33-40.

Blanco-Urgoiti, B., Sanchez, F., Perrez de San Roman, C., Dopazo, J., and Ponz, F. 1998. Potato virus $\mathrm{Y}$ group $\mathrm{C}$ isolates are a homogeneous pathotype but two different genetic strains. J. Gen. Virol. 79:2037-2042.

Blanchard, A., Rolland, M., Lacroix, C., Kerlan, C., and Jacquot, J. 2008. Potato virus Y: A century of evolution. Curr. Top. Virol. 7:21-32.

Boonham, N., Walsh, K., Hims, M., North, J., and Barker, I. 2002. Biological and sequence comparisons of Potato virus $Y$ isolates associated with potato tuber necrotic ringspot disease. Plant Pathol. 51:117-126.

Büchen-Osmond, C., Crabtree, K., Gibbs, A., and McLean, G., eds. 1988. Viruses of Plants in Australia. The Australian National University Printing Service, Canberra, Australia.

Calvert, E. L., Cooper, P., and McClure, J. 1980. An aphid transmitted strain of PVY-C recorded in potatoes in Northern Ireland. Rec. Agric. Res. Dept. Agric. Northern Ireland 28:63-74.

Cheng, Y., Jones, R. A. C., and Thackray, D. J. 2002. Deploying strain specific hypersensitive resistance to diminish temporal virus spread. Ann. Appl. Biol. 140:69-79.

Chikh Ali, M., Karasev, A. V., Furutani, N., Taniguchi, M., Kano, Y., Sato, M., Natsuaki, T., and Maoka, T. 2013. Occurrence of Potato virus $Y$ strain PVY ${ }^{\mathrm{NTN}}$ in foundation seed potatoes in Japan, and screening for symptoms in Japanese potato cultivars. Plant Pathol. 62:1157-1165.

Chikh-Ali, M., Rowley, J. S., Kuhl, J., Gray, S., and Karasev, A. V. 2014. Evidence of a monogenic nature of the $\mathrm{Nz}$ gene against Potato virus $Y$ strain $\mathrm{Z}\left(\mathrm{PVY}^{\mathrm{Z}}\right)$ in potato. Am. J. Potato Res. 91:649-654.

Chikh-Ali, M., Vander Pol, D., Nikolaeva, O. V., Melzer, M. J., and Karasev, A. V. 2016. Biological and molecular characterization of a tomato isolate of Potato virus $\mathrm{Y}$ (PVY) of the PVYC ${ }^{\mathrm{C}}$ lineage. Arch. Virol. 161:3561-3566.

Clark, M. F., and Adams, A. N. 1977. Characteristics of the microplate method of enzyme-linked immunosorbent assay for the detection of plant viruses. J. Gen. Virol. 34:475-483.

Cockerham, G. 1939. The distribution and significance of certain potato viruses in Scotland. Scot. J. Agric. 22:1-11.

Cockerham, G. 1943. The reactions of potato varieties to viruses X, A, B and C. Ann. Appl. Biol. 30:338-344.

Cockerham, G. 1970. Genetical studies on resistance to potato viruses X and Y. Heredity 25:309-348.
Coutts, B. A., and Jones, R. A. C. 2015. Potato virus Y: Contact transmission, stability on surfaces, and inactivation with disinfectants. Plant Dis. 99:387-394.

Davidson, T. M. W. 1980. Breeding for resistance to virus disease of the potato (Solanum tuberosum) at the Scottish Plant Breeding Station. Pages 100-108 in: Scottish Plant Breeding Station Annual Report for 1979-1980, Pentlandfield, Scotland.

Davidson, T. M. W., and Butzonitch, I. P. 1978a. The grouping of some strains of virus $\mathrm{Y}$ in relation to resistant cultivars. Page 161 in: Proc. 7th Triennial Conf. Eur. Assoc. Potato Res.

Davidson, T. M. W., and Butzonitch, I. P. 1978b. The grouping of some strains of virus $\mathrm{Y}$ in relation to resistant cultivars. Scottish Plant Breeding Station Report, Pentlandfield, Scotland.

de Bokx, J. A., and Huttinga, H. 1981. Potato virus Y. Descriptions of Plan Viruses, No. 242. Commonw. Mycol. Inst./Assoc. Appl. Biol, Kew, England.

De Bokx, J. A., Kratchanova, B., and Maat, D. Z. 1975. Some properties of a deviating strain of potato virus Y. Potato Res. 18:38-51.

de Bokx, J. A., and van der Want, J. P. H., eds. 1987. Viruses of potatoes and seed-potato production, 2nd ed. Centre for Agricultural Publishing and Documentation, Wageningen, The Netherlands.

del Pozo, O., and Lam, E. 2003. Expression of the baculovirus p35 protein in tobacco affects cell death progression and compromises $N$ gene-mediated disease resistance response to Tobacco mosaic virus. Mol. Plant-Microbe Interact. 16:485-494.

ECPD. 2017. European cultivated potato database. Online publication. Scottish Agricultural Science Academy, East Craigs, Edinburgh, Scotland. https:// www.europotato.org/menu.php

FAOSTAT. 2017. Food and agriculture data. Food and Agriculture Organization of the United Nations. http://www.fao.org/faostat/en/\#data

Funke, C. N., Nikolaeva, O. V., Green, K. J., Tran, L. T., Chikh-Ali, M., QuinteroFerrer, A., Cating, R. A., Frost, K. E., Hamm, P. B., Olsen, N., Pavek, M. J., Gray, S. M., Crosslin, J. M., and Karasev, A. V. 2017. Strain-specific resistance to Potato virus $Y(\mathrm{PVY})$ in potato and its effect on the relative abundance of PVY strains in commercial potato fields. Plant Dis. 101:20-28.

Gibbs, A. J., Ohshima, K., Yasaka, R., Mohammad, M., Gibbs, M. J., and Jones, R. A. C. 2017. The phylogenetics of the global population of potato virus Y and its necrogenic recombinants. Virus Evol. 3:vex002.

Glendinning, D. R. 1983. Potato introductions and breeding up to the 20th century. New Phytol. 94:479-505.

Gray, S., De Boer, S., Lorenzen, J., Karasev, A., Whitworth, J., Nolte, P., Singh, R., Boucher, A., and Xu, H. 2010. Potato virus Y: An evolving concern for potato crops in the United States and Canada. Plant Dis. 94:1384-1397.

Green, K., Chikh-Ali, M., Hamasaki, R., Melzer, M. J., and Karasev, A. Potato virus $Y$ (PVY) isolates from Physalis peruviana are unable to systemically infect potato or pepper and form a distinct new lineage within the $\mathrm{PVY}^{\mathrm{C}}$ strain group. Phytopathology. In press. doi:10.1094/PHYTO-04-17-0147-R

Hajimorad, M. R., Eggenberger, A. L., and Hill, J. H. 2005. Loss and gain of elicitor function of Soybean mosaic virus G7 provoking Rsv1-mediated lethal systemic hypersensitive response maps to P3. J. Virol. 79:1215-1222.

Heath, R. R., Sward, R. J., Moran, J. R., Mason, A. J., and Hallam, N. D. 1987 Biological characterization of six Australian isolates of potato virus $\mathrm{Y}$ and their serological detection by ELISA. Aust. J. Agric. Res. 38:395-402.

Hovarth, J. 1967. Studies on strains of potato virus Y. 4, anomalous strains. Acta Phytopathol. Acad. Sci. Hung. 2:195-210.

Howard, H. W., and Fuller, M. 1965. The inheritance of top necrosis to potato viruses X, A, B and C in Solanum tuberosum. Euphytica 14:189-195.

Hutton, E. M. 1945. The relationship between necrosis and resistance to virus Y in the potato. II. Some genetic aspects. J. Counc. Sci. Ind. Res. (Aust.) 18:219-24

Hutton, E. M. 1946. The relationship between necrosis and resistance to virus $Y$ in the potato. III. Interrelation with virus C. J. Counc. Sci. Ind. Res. (Aust.) 19: 273-282.

Hutton, E. M. 1948. Some factors affecting localized and systemic necrotic reactions to virus $\mathrm{Y}$ in the potato. Aust. J. Biol. Sci. 1:416-438.

Hutton, E. M. 1951. Possible genotypes conditioning virus resistance in the potato and tomato. J. Aust. Inst. Agric. Sci. 17:132-138.

Hutton, E. M., and Bald, J. G. 1945. The relationship between necrosis and resistance to virus $\mathrm{Y}$ in the potato. I. Greenhouse results. J. Counc. Sci. Ind Res. (Aust.) 18:48-52.

Jones, R. A. C. 1981. The ecology of viruses infecting wild and cultivated potatoes in the Andean Region of South America. Pages 89-107 in: Pests, Pathogens and Vegetation. J. M. Thresh, ed. Pitman, London.

Jones, R. A. C. 1987. Problems associated with potyviruses in potato certification field inspection and serological testing. EPPO Bull. 17:61-67.

Jones, R. A. C. 1990. Strain group specific and virus specific hypersensitive reactions to infection with potyviruses in potato cultivars. Ann. Appl. Biol. 117:93-105.

Jones, R. A. C. 2005. Patterns of spread of two non-persistently aphid-borne viruses in lupin stands under four different infection scenarios. Ann. Appl Biol. 146:337-350.

Jones, R. A. C. 2014. Virus disease problems facing potato industries worldwide: Viruses found, climate change implications, rationalising virus strain nomenclature and addressing the Potato virus $Y$ issue. Pages 202-224 in The Potato: Botany, Production and Uses. R. Navarre and M. J. Pavek, eds. CABI, Wallingford, UK. 
Jones, R. A. C., Coutts, B. A., and Cheng, Y. 2003. Yield limiting potential of necrotic and non-necrotic strains of Bean yellow mosaic virus in narrowleafed lupin (Lupinus angustifolius). Aust. J. Agric. Res. 54:849-859.

Jones, R. A. C., and Fribourg, C. E. 1986. Potato virus V. Descriptions of Plant Viruses No. 316. Association of Applied Biologists, Wellesbourne, UK.

Jones, R. A. C., and Fuller, N. J. 1984. Incidence of potato virus V in potato stocks in England and Wales. Plant Pathol. 33:595-597.

Jones, R. A. C., and Kehoe, M. A. 2016. A proposal to rationalize within-species plant virus nomenclature: Benefits and implications of inaction. Arch. Virol. 161:2051-2057.

Jones, R. A. C., and Smith, L. J. 2005. Inheritance of hypersensitive resistance to Bean yellow mosaic virus in narrow-leafed lupin (Lupinus angustifolius). Ann. Appl. Biol. 146:539-543.

Karasev, A. V., and Gray, S. M. 2013a. Continuous and emerging challenges of Potato virus $Y$ in Potato. Annu. Rev. Phytopathol. 51:571-586.

Karasev, A. V., and Gray, S. M. 2013b. Genetic diversity of Potato virus $Y$ complex. Am. J. Potato Res. 90:7-13.

Kehoe, M. A., and Jones, R. A. C. 2011. A proposal to help resolve the disagreement between naming of potato virus $\mathrm{Y}$ strain groups defined by resistance phenotypes and those defined by sequencing. Arch. Virol. 156: 2273-2278.

Kehoe, M. A., and Jones, R. A. C. 2016. Improving Potato virus $Y$ strain nomenclature: Lessons from comparing isolates obtained over a 73 year period. Plant Pathol. 65:322-333.

Kerlan, C. 2006. Potato virus Y. Descriptions of Plant Viruses, No. 414. Association of Applied Biologists, Wellesbourne, UK.

Kerlan, C., and Moury, B. 2008. Potato virus Y. Pages 287-296 in: Encyclopedia of Virology, 3rd ed. A. Granoff and R. Webster, eds. Academic Press, New York.

Kerlan, C., Nikolaeva, O. V., Hu, X., Meacham, T., Gray, S. M., and Karasev, A. V. 2011. Identification of the molecular make-up of the Potato virus $Y$

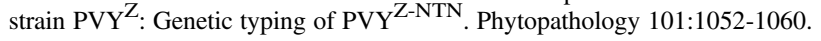

Kim, B., Masuta, C., Matsuura, H., Takahashi, H., and Inukai, T. 2008. Veinal necrosis induced by Turnip mosaic virus infection in Arabidopsis is a form of defence response accompanying HR-like cell death. Mol. Plant-Microbe Interact. 21:260-268.

Loebenstein, G., Berger, P. H., Brunt, A. A., and Lawson, R. H., eds. 2001. Virus and Virus-like Diseases of Potatoes and Production of Seed-Potatoes. Kluwer Academic Publishers, Dordrecht, The Netherlands.

Moury, B., Caromel, B., Johansen, E., Simon, V., Chauvin, L., Jacquot, E., Kerlan, C., and Lefebvre, V. 2011. The helper component proteinase cistron of Potato virus $Y$ induces hypersensitivity and resistance in potato genotypes carrying dominant resistance genes on chromosome IV. Mol. Plant-Microbe Interact. 24:787-797.

Murphy, P. A. 1921. Investigations of potato diseases. Can. Dep. Agric. Bull. 44.

Nie, B., Singh, M., Murphy, A., Sullivan, A., Xie, C., and Nie, X. 2012. Response of potato cultivars to five isolates belonging to four strains of Potato virus $Y$. Plant Dis. 96:1422-1429.

Noordham, D. 1973. Identification of Plant Viruses-Methods and Experiments. Center for Agricultural Publishing and Documentation, Pudoc, Wageningen, The Netherlands.

Nyalugwe, E. P., Barbetti, M. J., Clode, P. L., and Jones, R. A. C. 2016. Systemic Hypersensitive resistance to Turnip mosaic virus in Brassica juncea is associated with multiple defence responses, especially phloem necrosis and xylem occlusion. Plant Dis. 100:1261-1270.
PANA. 2017. North American Potato Variety Inventory. Online publication. The Potato Association of North America, Orono, ME. http://potatoassociation.org/ publications/north-american-potato-variety-inventory

Ravelo, G., Kagaya, U., Inukai, T., Sato, M., and Uyeda, I. 2007. Genetic analysis of lethal tip necrosis induced by Clover yellow vein virus infection in pea. J. Gen. Plant Pathol. 73:59-65.

Rowley, J. S., Gray, S. M., and Karasev, A. V. 2015. Screening potato cultivars for new sources of resistance to Potato virus Y. Am. J. Potato Res. 92:38-48.

Rozendaal, A., van Binsbergen, J., Anema, B., van Slogteren, D. H .M., and Burt, M. H. 1971. Serology of a deviating strain of potato virus Y-C in the potato variety Gladblaadje. Potato Res. 14:21 (Abstr.).

Scholthof, K.-B. G., Adkins, S., Czosnek, H., Palukaitis, P., Jacquot, E., Hohn, T., Hohn, B., Saunders, K., Candresse, T., Ahlquist, P., Hemenway, C., and Foster, G. D. 2011. Top ten viruses in molecular plant pathology. Mol. Plant Pathol. 12: 938-954.

Singh, R. P., Valkonen, J. P. T., Gray, S. M., Boonham, N., Jones, R. A. C., Kerlan, C., and Schubert, J. 2008. Discussion Paper: The naming of Potato virus $Y$ strains infecting potato. Arch. Virol. 153:1-13.

Smith, K. M. 1931. On the composite nature of certain potato virus diseases of the mosaic group as revealed by the use of plant indicators and selective methods of transmission. Proc. Roy. Soc. London. Series B 109:251-267.

Smith, K. M. 1957. A Textbook of Plant Virus Diseases, 2nd ed. Churchill Ltd., London.

Solomon-Blackburn, R. M., and Barker, H. 2001. A review of host major-gene resistance to potato viruses $\mathrm{X}, \mathrm{Y}, \mathrm{A}$ and $\mathrm{V}$ in potato: Genes, genetics and mapped locations. Heredity 86:8-16.

Stevenson, W. R., Loria, R., Franc, G. D., and Weingartner, D. P., eds. 2001 Compendium of Potato Diseases, 2nd ed. American Phytopathological Society Press, St. Paul, MN.

Szajko, K., Chrzanowska, M., Witek, K., Strzelczyk-Żyta, D., Zagórska, H., Gebhardt, C., Hennig, J., and Marczewski, W. 2008. The novel gene $N y-1$ on potato chromosome IX confers hypersensitive resistance to Potato virus $Y$ and is an alternative to $R y$ genes in potato breeding for PVY resistance. Theor. Appl. Genet. 116:297-303.

Szajko, K., Strzelczyk-Żyta, D., and Marczewski, W. 2014. Ny-1 and Ny-2 genes conferring hypersensitive response to potato virus Y (PVY) in cultivated potatoes: Mapping and marker-assisted selection validation for PVY resistance in potato breeding. Mol. Breed. 34:267-271.

Thackray, D. J., Smith, L. J., Cheng, Y., Perry, J. N., and Jones, R. A. C. 2002 Effect of strain-specific hypersensitive resistance on spatial patterns of virus spread. Ann. Appl. Biol. 141:45-59.

Tian, Y. P., and Valkonen, J. P. T. 2013. Genetic determinants of Potato virus $Y$ required to overcome or trigger hypersensitive resistance to PVY strain group O controlled by the gene $N y$ in potato. Mol. Plant-Microbe Interact. 26:297-305.

Valkonen, J. P. T. 2007. Viruses: Economical losses and biotechnological potential. Pages 619-641 in: Potato Biology and Biotechnology: Advances and Perspectives. D. Vreugdenhil, ed. Elsevier, Amsterdam, The Netherlands.

Valkonen, J. P. T., Jones, R. A. C., Slack, S. A., and Watanabe, K. N. 1996 Resistance specificities to viruses in potato: Standardization of nomenclature. Plant Breed. 115:433-438.

Valkonen, J. P. T., and Makarainen, E. 1993. Symptom expression and accumulation of potato virus Y (PVYO) and potato leaf roll virus in thirteen potato cultivars. Agric. Sci. Finl. 2:33-40. 